\title{
AS TRADIÇÕES HISTÓRICAS INDÍGENAS DIANTE DA CONQUISTA E COLONIZAÇÃO DA AMÉRICA: TRANSFORMAÇÕES E CONTINUIDADES ENTRE NAHUAS E INCAS*
}

\author{
Eduardo Natalino dos Santos** \\ Doutorando no Depto. de História - FFLCH/USP
}

\begin{abstract}
Resumo
Apresentaremos neste artigo algumas das principais características de duas tradições históricas indígenas: a nahua e a inca. Em seguida, analisaremos comparativamente suas ações, reações, transformações e continuidades diante de desafios históricos similares e contemporâneos: as conquistas e as colonizações castelhanas do Altiplano Central Mexicano e dos Andes durante os séculos XVI e XVII.
\end{abstract}

\section{Pallavras-Chave}

Nahuas • Incas • Conquista e colonização castelhana • Tradições históricas indígenas • Fontes históricas indígenas

\section{Abstract}

This article presents some of the main characteristics of two indigenous historical traditions: the Nahua and the Inca. The author offers a comparative analysis of indigenous actions, reactions, adaptations, transformations, and continuities as they faced similar, contemporaneous challenges: the Spanish conquest and colonization of Central Mexico and the Andes during the seventeenth and eighteenth centuries.

\section{Keywords}

Nahua $\bullet$ Inca $\bullet$ Spanish conquest and colonization • Indigenous historical traditions • Indigenous historical sources

${ }^{*}$ Este trabalho teve como ponto de partida o curso Visão comparativa da conquista e colonização das sociedades indígenas estatais: nahuas, maias e incas, ministrado durante o primeiro semestre de 2002 no Depto. de História - FFLCH/USP pelo Prof. Dr. Federico Navarrete Linares (Instituto de Investigaciones Históricas - UNAM), a quem agradeço pelas críticas e sugestões.

\footnotetext{
** Bolsista Fapesp.
} 


\section{Introdução}

A elaboração e o uso social de explicações sobre o passado foram práticas constantes nas mais diversas sociedades humanas. Em geral, tais elaborações tratam de explicar e articular as origens, as transformações, as permanências e as expectativas grupais, dando-lhes sentidos supostamente imanentes, que funcionam, entre outras coisas, como elementos de coesão social. E essa imanência atribuída é socialmente entendida e aceita, em parte, pelo fato de que tais explicações são construídas sobre as amplas concepções que cada sociedade possui - e compartilha de forma mais ou menos homogênea, dependendose do caso - acerca do tempo, do espaço, da transformação, da permanência, da origem, do destino, do que seja acontecimento, fato, verdade e etc; e que formam um todo mais ou menos coerente, mas não monolítico, que podemos chamar de visão de mundo. ${ }^{1}$

A construção e a manutenção de explicações históricas com aceitação social é um processo de média ou longa duração e, em geral, sobretudo nas chamadas sociedades complexas, tende a estar sob o controle de camadas sociais específicas, que podem, inclusive, contar com indivíduos ou instituições especializados na produção, na transmissão e na difusão de tais explicações, comoé o caso das sociedade indígenas que analisaremos. Chamaremos de tradições históricas a essas organizações, grupos, instituições ou indivíduos que se dedicam de forma sistemática mas não necessariamente exclusiva - à construção, manutenção e transformação de explicações socialmente aceitas acerca do passado.

E tudo isso - a relação das tradições históricas com determinados grupos sociais e a ligação de suas construções com uma determinada visão de mundo - nos leva à conclusão de que é imprescindível entender as explicações sobre o passado como produtos históricos específicos, inseridos em um conjunto de problemas que se relaciona diretamente com a sociedade em questão. ${ }^{2}$

\footnotetext{
${ }^{1} \mathrm{O}$ conceito visão de mundo pode ser definido como um "Conjunto articulado de sistemas ideológicos relacionados entre sí en forma relativamente congruente, con el que un individuo o un grupo social, en un momento histórico, pretende aprehender el universo." (López Austin 2002).

${ }^{2}$ No entanto, é muito comum que as explicações produzidas pelas tradições não ocidentais - sobretudo pelas tradições indígenas - sejam analisadas e caracterizadas de forma conjunta e genérica, como se fossem o resultado da ação de princípios ou leis univer-
} 
Essas são as idéias gerais que orientaram a elaboração deste artigo, o qual tem como objetivo específico apresentar algumas das principais características das tradições históricas nahua e inca, para depois analisar, comparativamente, suas diferentes ações, reações, transformações e continuidades diante de processos históricos similares, contemporâneos e levados às regiões do Altiplano Central Mexicano e dos Andes Centrais por um agente histórico comum. Estamos nos referindo às conquistas e colonizações castelhanas dos séculos XVI e XVII.

$\mathrm{O}$ entendimento dessas diferentes tradições e de suas distintas reações e transformações diante da empresa colonial castelhana é fundamental para podermos contextualizar e analisar adequadamente os escritos históricos ${ }^{3}$ produzidos nessas duas regiões durante o Período Colonial ${ }^{4}$, sejam os escritos de origem e estrutura mais próximas ao pensamento nahua ou inca, ou sejam os escritos tipicamente ocidentais que, de alguma maneira, utilizaram-se das informações provenientes das tradições históricas locais. ${ }^{5}$

sais, que regeriam o pensamento de suas sociedades produtoras - chamado de pensamento mítico. Partindo desse pressuposto, tais análises procuram determinar as características formais e conceituais comuns a tais explicações, independentemente das especificidades sociais e históricas em meio das quais foram produzidas. Veremos, por exemplo, que as tradições históricas mesoamericanas utilizavam um preciso sistema de calendário como elemento organizador de suas narrativas. Esse sistema funcionava como uma espécie de coluna vertebral das narrativas e permitia a marcação de uma inequívoca seqüência temporal diacrônica, fato que não excluía a presença da sincronia nos relatos. Apesar disso, pouca atenção tem sido dada a esse caráter diacrônico do pensamento mesoamericano, predominando a ênfase no caráter cíclico ou sincrônico, o qual condiz mais facilmente com o pressuposto de que fora do mundo ocidental predomina o pensamento mítico, caracteristicamente sincrônico e não preocupado em delimitar a fronteira presente-passado.

${ }^{3}$ Estou chamando de escritos históricos ao conjunto de textos que, de modo central e explícito, possuem como tema as histórias e os costumes dos povos americanos.

${ }^{4}$ Esse raciocínio também pode ser aplicado, de modo mais geral, para ajudar a explicar as distintas ações, reações e transformações das sociedades indígenas americanas frente ao processo de conquista e colonização castelhanas. Em outras palavras, somente entendendo as especificidades das diversas sociedades indígenas - inclusive suas construções ideológicas sobre a chegada e a presença do europeu - é que poderemos compreender os diferentes contatos, convivências e conflitos que foram construídos entre os povos locais e os estrangeiros a partir do século XVI.

${ }^{5}$ Em outra ocasião, tratamos da produção de crônicas e histórias pelos religiosos espanhóis e do uso que fizeram das informações provenientes das tradições indígenas mesoamericanas (Santos 1998). 


\section{1 - As tradições históricas nahua e inca}

É muito difícil fazer uma caracterização eqüitativa das tradições históricas inca e nahua durante o período Pré-hispânico ou Colonial. O conhecimento acerca dessas tradições - que possuem em comum o fato de pertencer a sociedades estamentais e dominadoras que foram alvos das primeiras guerras de conquistas castelhanas - depende, muitas vezes, de fatores alheios à boa vontade do pesquisador, dentre os quais podemos destacar: a sobrevivência ou não de registros produzidos por tais tradições; o entendimento de seus eventuais sistemas de registro; a existência ou não de escritos alfabéticos coloniais, produzidos por indígenas ou castelhanos, que registrem depoimentos da vertente oral, "traduzam" parte dos registros tradicionais ou que, pelo menos, descrevam o funcionamento de tais tradições; e, por fim, a continuidade ou não dessas tradições até tempos recentes.

A positividade ou negatividade de cada um desses fatores determina, em parte, a possibilidade de existência de um campo de estudo específico, que se dedique aos registros tradicionais, aos escritos alfabéticos coloniais ou aos grupos humanos que mantiveram tais tradições até tempos mais recentes. A articulação dos conhecimentos oriundos desses diversos campos de estudo pode nos fornecer a possibilidade de entendermos, pelo menos em parte, o funcionamento de tais tradições e de seus registros em tempos pré-hispânicos ou coloniais.

Tal articulação tem sido mais afortunada no caso da tradição nahua do que no caso da inca, pois existe um grande desequilíbrio, qualitativo e quantitativo, no conhecimento das fontes provenientes dessas tradições históricas, bem como no conhecimento de informações coloniais acerca de seus funcionamentos.

O desequilíbrio qualitativo deve-se principalmente ao fato de reconhecermos como tais e entendermos apenas os sistemas escriturários empregados tradicionalmente na Mesoamérica, os quais serviram para a produção de um sem número de registros sobre papel, pele, pedra, cerâmica e outros materiais. Enquanto que no caso andino, reconhecemos e entendemos tão somente as complexas dimensões numéricas dos quipus, registro que servia-se de conjuntos de cordões de distintas cores e comprimentos, articulados entre si de diversas formas e com nós em distintas posições. Os quipus mais simples possuíam um cordel horizontal principal, ao qual se atavam cordéis verticais secundários, nos quais registravam-se, de acordo com a quantidade de nós e suas 
posições relativas entre si e entre o cordel principal, as unidades, dezenas, centenas e etc. $^{6}$

No entanto, além desse simples esquema de dois tipos de cordéis, muitos quipus apresentavam cordéis duplos, triplos, com cores diferentes e com diferentes tipos de nós, elementos esses que possivelmente também possuíam seus significados. Desse modo, paira sobre os quipus uma enorme dúvida: eram ou não utilizados também para o registro de informações não numéricas?

Pesa a favor dos que defendem que os quipus eram utilizados apenas para registros numéricos ${ }^{7}$ o fato de não possuirmos nenhuma "leitura", "tradução" ou versão colonial reconhecida e aceita de seus supostos conteúdos não-numéricos, apesar de que, como veremos, alguns cronistas do início do Período Colonial relataram que seus informantes andinos utilizavam-se de quipus para responder aos questionamentos acerca de suas origens e história. Tais relatos coloniais são utilizados como argumento pelos que defendem que os quipus serviam também para o registro de informações não-numéricas ${ }^{8}$, as quais serviam de base para narrativas que dependiam de uma tradição oral articulada. Desse modo, creio que não devemos dar a polêmica por encerrada. Voltaremos a essa polêmica ao tratarmos especificamente de caracterizar a tradição histórica inca.

De qualquer modo, ao contrário do caso do México Central, no caso andino não possuímos "textos" tradicionais, sejam pré-hispânicos ou coloniais, pois se os quipus sobreviventes possuem dimensões narrativas, ainda não podemos entendê-las.

O desequilíbrio quantitativo caracteriza-se pelo fato de que o número de documentos baseados nos quipus ou na reconhecida oralidade das tradições históricas andinas produzidos durante o século XVI e princípios do século XVII é infinitamente menor do que a quantidade produzida no México Central. Essa escassez de "traduções" para línguas européias ou de transliterações em línguas locais dos registros ou narrativas tradicionais - ou ainda a impossibilidade de entender totalmente os quipus - compromete as possibilidades de

\footnotetext{
${ }^{6}$ Vale notar que nos Andes, diferentemente da Mesoamérica, onde era utilizado o sistema numérico vigesimal, predominou o sistema decimal.

${ }^{7}$ Dentre os quais podemos destacar Pease 1995.

${ }^{8}$ Dentre os quais podemos destacar Ascher \& Ascher 1995.
} 
entendimento do funcionamento e das principais características das tradições históricas incas e andinas em geral.

Bem diferente é o caso do México Central, onde reconhecidamente havia um sistema de escrita pictoglífica ${ }^{9}$, com o qual se produziram numerosos documentos em tempos pré-hispânicos e coloniais, dos quais alguns exemplares tradicionais e muitos adaptados às demandas coloniais chegaram até nós. ${ }^{10}$

Além disso, esses documentos pictoglíficos tiveram parte de seus conteúdos "traduzidos" ou explicados em textos alfabéticos em línguas indígenas e européias, com os quais, pese a todos os problemas envolvidos nesse processo, podemos entender um pouco mais das principais características das tradições de pensamento histórico dessa região. Em suma, houve um maior reconhecimento por parte dos castelhanos das tradições históricas nahuas - e conseqüentemente um número maior de trabalhos coloniais conjuntos de transcrições e "traduções" - do que das tradições incas. Talvez isso tenha ocorrido porque a estrutura narrativa em anais e a escrita pictoglífica utilizadas na Mesoamérica fossem, relativamente, mais parecidas às concepções históricas e ao sistema de escrita cristãos do que as concepções incas do 162 passado e sua menor importância atribuída à cronologia, além de suas relações com a paisagem por meio dos ceques e de seus distintos sistemas de registro, como os quipus. ${ }^{11}$

\footnotetext{
${ }^{9}$ Prefiro o termo pictoglífico a pictográfico por acreditar que ele evoca, de forma mais explícita, a combinação entre elementos pictóricos e glíficos, a qual era uma das principais características do sistema de escrita mixteco-nahua. Em outra ocasião tivemos a oportunidade de analisar algumas das soluções figurativas empregadas nos códices nahuas e pudemos comprovar que os problemas relacionados à semântica eram prioritários em relação aos de reprodução realística da dimensão visual do mundo (Santos 2003).

${ }^{10}$ Do Altiplano Central procedem dois manuscritos de formato, estilo, e características tradicionais, mas cuja datação é controversa. São eles os códices Borbónico e Aubin. São considerados como pré-hispânicos os códices Bórgia, Cospi, Féjérváry-Mayer, Laud e Vaticano B (grupo Bórgia); Becker $n^{o}$. 1, Bodley, Colombino, Nuttall e Viena (grupo Nuttall). Todos esses procedem da região de Cholula, Tlaxcala e oeste de Oaxaca, da qual procedem também o Códice Selden, do grupo Nuttall, mas cuja datação é controversa. Da região maia procedem três códices pré-hispânicos: o de Dresde, o de Paris e o de Madri, formado pelos códices Cortesiano e Troano e por isso também chamado de Tro-cortesiano (Glass 1975).

${ }^{11}$ Frank Salomon, em uma análise da crônica de Titu Cusi Yupanqui, propõe que as duas tradições de escrita e pensamento histórico - a cristã e a inca - eram tão diferentes e irredutíveis que as "traduções" eram virtualmente impossíveis (Salomon 1982).
} 
Como uma espécie de compensação, que não chega a equilibrar nosso conhecimento das duas tradições, no caso andino temos uma acentuada continuidade da oralidade. Tal continuidade se deveu, em parte, ao estabelecimento e à manutenção de uma sociedade colonial extremamente cindida e que se manteve até tempos mui recentes: de um lado, os castelhanos e seus descendentes, ocupantes da costa; e por outro, os grupos indígenas, refugiados ou habitantes tradicionais das montanhas. Essa cisão, apesar de seu caráter de violência e de exclusão, possibilitou a continuidade e a transformação mais lenta de várias comunidades andinas e suas tradições históricas orais, o que tornou possível a realização de estudos antropológicos durante o século XX. ${ }^{12}$

\section{A - Nahuas e Mesoamérica}

Penso que entre as diversas características da tradição histórica nahua, três merecem destaque por sua quase onipresença nos registros pictoglíficos e na oralidade transcrita durante o Período Colonial: 1 - a utilização de um preciso e complexo sistema calendário ${ }^{13}$ como elemento central na organização intelectual das explicações acerca do passado; 2 - a localização da época atual após uma seqüência de eras ou idades, cujos inícios e finais teriam sido marcados por criações e destruições cósmicas parciais; 3 - a centralidade temática do altepetl e seus pipiltin ${ }^{14}$ nas narrativas acerca do passado mais recente.

Essas características não são exclusivas dos povos nahuas. São encontradas em grupos mesoamericanos anteriores à migração desses povos à Mesoamérica - como por exemplo os maias e os mixtecos. Aliás, a presença dessas características - aliadas a uma série de outras - tem servido justamente para que se estabeleça a pertinência de um grupo à região cultural mesoamericana, cuja fronteira norte durante o Período Clássico, aproximadamente do início da Era Cristã ao século IX, encontrava-se muito mais ao norte do que durante a época

\footnotetext{
${ }^{12}$ Para completar o desequilíbrio, podemos agregar a desigualdade de meu conhecimento, como estudioso do México Central, em relação às tradições históricas das duas regiões.

${ }^{13} \mathrm{Na}$ língua portuguesa a palavra calendário e suas variações de gênero e número podem ser substantivos ou adjetivos (Vocabulário ortográfico da língua portuguesa 1999: 130).

${ }^{14}$ Termos em nahuatl que podem ser traduzidos, respectivamente, por cidade ou entidade política independente e nobreza local.
} 
de predomínio dos grupos toltecas e nahuas, isto é, dos séculos X ao XVI. Além disso, as regiões ao norte - Aridamérica e Oasisamérica - mantinham constantes relações com a Mesoamérica, o que torna possível que algumas dessas características, típicas das tradições históricas mesoamericanas, fossem compartilhadas com os grupos setentrionais, como os nahuas, muito antes de suas migrações em direção ao sul.

De qualquer modo, depois da decadência dos grandes e hegemônicos centros urbanos teotihuacanos, zapotecas e maias, cujo predomínio político e cultural caracterizou o Período Clássico, essas características passaram a ser parte integrante das tradições históricas toltecas e nahuas. Esses grupos obtiveram uma relativa hegemonia política e cultural na Mesoamérica no Período Pós-clássico e, simultaneamente, adotaram, mantiveram e transformaram antigas características culturais mesoamericanas, entre as quais se encontrava o sistema de calendário, a concepção das idades anteriores do mundo e a centralidade dos altepeme $e^{15}$ e seus dirigentes na cosmologia, cosmografia e história. Na região central do México, os novos centros desses novos senhores mesoamericanos foram Tula, Azcapotzalco e, por fim, México-Tenochtitlan.

164 Tratemos então das três características mencionadas acima e da importância que possuíam para as tradições históricas nahuas.

Podemos dizer que a base do sistema calendário mesoamericano era a conta dos dias, realizada por meio da combinação de um conjunto de vinte signos, chamados de tonalli, com um conjunto de treze números que, juntos, serviam para nomear os dias. O conjunto dos tonalli era composto por animais, plantas, artefatos humanos, fenômenos naturais e conceitos abstratos, como podemos observar na Tabela 1, que traz seus nomes em nahuatl e suas respectivas traduções.

\footnotetext{
${ }^{15}$ Plural de altepetl.
} 


\section{Tabela 1: Os vinte tonalli}

\begin{tabular}{|c|c|c|c|c|}
\hline $\begin{array}{c}\text { शू⿹ } \\
\text { I } \\
\text { Cipactli } \\
\text { Jacaré }\end{array}$ & $\begin{array}{l}\text { Ehecatl } \\
\text { Vento }\end{array}$ & $\begin{array}{l}\text { III Calli } \\
\text { Casa }\end{array}$ & $\begin{array}{c}\text { Cuetzpalin } \\
\text { Lagarto }\end{array}$ & 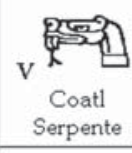 \\
\hline $\begin{array}{c}\text { VI } \\
\text { Miquiztli } \\
\text { Morte }\end{array}$ & VII & $\begin{array}{l}\text { VIII } \\
\text { Tochtli } \\
\text { Coelho }\end{array}$ & 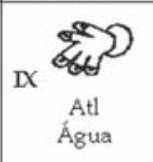 & Itzcuintli \\
\hline 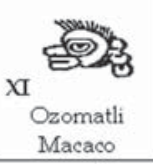 & $\begin{array}{c}\text { Malinalli } \\
\text { Erva }\end{array}$ & $\begin{array}{c}\text { XII } \stackrel{\text { 国 }}{\text { Acatl }} \\
\text { Cana ou junco }\end{array}$ & $\begin{array}{c}\text { Xcelotl } \\
\text { Jaguar } \\
\text { Octo }\end{array}$ & $\begin{array}{l}\text { XV } \\
\text { Cuauhtli } \\
\text { Águia }\end{array}$ \\
\hline $\begin{array}{l}\text { XvI } \\
\begin{array}{c}\text { Cozcacuauhtli } \\
\text { Urubu }\end{array}\end{array}$ & $\underset{\substack{\text { XVIII } \\
\text { Movimento }}}{\sum\{}$ & $\begin{array}{l}\text { XVIII } \\
\text { Tecpatl } \\
\text { Punhal }\end{array}$ & $\begin{array}{l}\text { Quiahuitl } \\
\text { Chuva }\end{array}$ & है \\
\hline
\end{tabular}

Esse ciclo de 260 dias chamava-se tonalpohualli, palavra proveniente do nahuatl e formada por tonalli, que significa ardor, calor do sol, tempo de estio e que era empregada como sinônimo de dia, e por tlapohualli, que significa coisa contada ou numerada. Desse modo, poderíamos traduzir tonalpohualli como contar os dias. ${ }^{16}$

Mas é interessante notar que tonalli também significa alma, espírito, razão, parte, porção, o que é destinado a alguém ou destino, e que tlapohualli também significa história dita ou relatada. E assim, tonalpohualli poderia ser traduzido também como relatar ou contar algo sobre as almas, sobre o quinhão de cada um, sobre o que é destinado a cada ser. ${ }^{17}$ Veremos que essa estreita relação

\footnotetext{
${ }^{16}$ Esse ciclo de 260 dias era dividido em 20 trezenas, que eram registradas de maneira sincrônica em livros pictoglíficos com finalidades mânticas e chamados de tonalamatl. Esses livros eram utilizados por sacerdotes especializados em prognósticos, que envolviam todas as esferas da vida: nascimentos, mortes, enfermidades, guerras, plantios, colheitas e etc. Não entraremos em detalhe sobre esse ciclo e seus livros correspondentes pelo fato de que o foco deste artigo será o uso que as tradições históricas nahuas faziam de um outro ciclo calendário: a conta dos anos.

${ }^{17}$ Todas as análises dos termos em nahuatl e suas traduções foram feitas a partir do vocabulário do frei Alonso de Molina (Molina 2001) e do dicionário de Rémi Siméon (Rémi Siméon 1997).
} 
entre contar o tempo e narrar sobre os destinos permeava o pensamento histórico nahua e era utilizada também na conta dos anos e seus registros, dois quais trataremos a seguir.

A partir da conta dos dias, os povos mesoamericanos nomeavam e contavam os anos sazonais, cuja duração havia sido precisamente definida em 365 dias. ${ }^{18} \mathrm{O}$ nome do primeiro dia do ano sazonal no tonalpohualli servia para nomeá-lo. Imaginemos que hoje é o dia 1 acatl (cana) e que esse é o primeiro dia do ano sazonal: esse ano se chamará 1 acatl. Mas como o ano sazonal é maior do que o ciclo de 260 dias, o próximo ano sazonal não começará novamente no dia 1 acatl mas no $106^{\circ}$. dia do ciclo seguinte do tonalpohualli. Que dia será esse? Os vinte signos do tonalpohualli cabem dezoito vezes no ano sazonal de 365 dias e sobram cinco dias, isto faz que o signo que nomeia o ano, chamado de portador ou carregador do ano, salte de cinco em cinco signos dentre os vinte tonalli. Como o conjunto dos signos é formado por vinte, ao final de quatro anos se regressa ao primeiro signo. Em outras palavras, se o primeiro ano teve como signo acatl, que é o décimo terceiro signo, o segundo ano terá o décimo oitavo signo, isto é, tecpatl, o terceiro ano terá o terceiro 166 signo, isto é, calli, o quarto ano terá o oitavo signo, isto é, tochtli, e no quinto ano volta-se ao signo acatl. Portanto, dentre os vinte signos do tonalli, apenas quatro serviam para nomear os anos.

\footnotetext{
${ }^{18}$ Há uma polêmica acerca da utilização de mecanismos de ajuste entre o ciclo calendário de 365 dias e a duração do ano solar, aproximadamente de 365 dias e um quarto. Alguns estudiosos, como Víctor Castillo Farreras (Castillo Farreras 1971), acreditam que havia uma espécie de ano bissexto ou correções regulares, mecanismo indispensável para que o início do ano calendário e suas subdivisões coincidissem de maneira regular com as estações. Outros estudiosos, como Michel Graulich (Graulich 1990), acreditam que não existia tal mecanismo e que ao longo do tempo houve uma grande defasagem entre o início do ano calendário, suas subdivisões e as estações. Um outro grupo de estudiosos, dentre os quais podemos citar Gordon Brotherston (Brotherston 1997), propõe ainda que um sistema de calendário que teve uma continuidade de uso tão ampla e que possuía subdivisões do ano marcadas por celebrações e festividades claramente relacionadas com as estações, seguramente possuía um mecanismo de correção. Acreditam, no entanto, que tal mecanismo não era empregado de modo tão regular como o mecanismo do ano bissexto, e que funcionava a partir da observação dos solstícios e da conferência da posição das Plêiades no meio da noite em que se comemorava o início do ano calendário, quando então essa constelação deveria ocupar o zênite. A defasagem da ocorrência do solstício e da posição das Plêiades em relação ao calendário poderia servir para, de tempos em tempos, se fazer correções. Para um balanço geral da questão: Tena 1992.
} 
Mas e quanto aos números que acompanham os vinte signos do tonalli para nomear os dias? Será que apenas quatro números acompanhavam os quatro signos do tonalli que nomeavam os anos? Isso aconteceria se tivéssemos vinte números para acompanhar os vinte signos do tonalli, pois desse modo teríamos uma seqüência de vinte combinações fixas entre os números e os signos na conta dos dias. Mas vimos que eram treze os números que se combinavam com os vinte signos para nomear os dias e, conseqüentemente, para nomear os anos. Como os treze números do tonalpohualli cabem vinte e oito vezes no ano sazonal de 365 dias e sobra um, os números dos dias com os quais os anos iniciam-se avançam de um em um. Em outras palavras, se o primeiro ano teve como dia inicial 1 acatl, o segundo ano terá 2 tecpatl, o terceiro ano terá 3 calli, o quarto ano terá 4 tochtli, o quinto ano terá 5 acatl e assim sucessivamente até se operarem todas as possíveis combinações entre os quatro signos e os treze números que caem como dias iniciais dos anos sazonais, o que resulta em uma série de 52 anos, após os quais os nomes dos anos se repetem.

Esses anos sazonais eram chamados de xihuitl e seu ciclo de 52 anos era chamado de xiuhmolpilli. ${ }^{19}$ Esse ciclo calendário de 52 anos sazonais era a base organizacional dos livros em forma de anais chamados xiuhamatl, por meio dos quais diversos grupos mesoamericanos narraram a história do próprio grupo, suas origens, migrações, guerras e dinastias reinantes.

Vale notar que os dois ciclos - o de 260 e o de 365 dias - integravam-se perfeitamente, formando um só sistema, pois a repetição da combinação entre ambos dava-se justamente a cada 52 anos sazonais ou 73 ciclos de 260 dias, pois nos dois casos temos um total de 18.980 dias. ${ }^{20}$ Quando o primeiro dia do xihuitl encontrava-se com o primeiro dia do tonalpohualli se celebrava a festa

\footnotetext{
${ }^{19}$ Além disso, cada ano sazonal era dividido em dezoito períodos de vinte dias - chamados de vintenas e marcados pela passagem completa dos vinte signos do tonalli - mais cinco dias finais considerados baldios ou ocos - chamados de nemontemi. Em outras palavras, o ano que se iniciou, por exemplo, com 1 acatl teria todas suas dezoito vintenas iniciadas com acatl e depois cinco dias finais considerados aziagos.

${ }^{20}$ A integração entre os dois ciclos que formam o sistema de calendário mesoamericano é tão complexa e completa que, em última instancia, podemos considerar o xiuhmolpilli, isto é, o ciclo de 52 anos sazonais, como uma das partes de um grande tonalpohualli de anos sazonais, pois 52 é a quinta parte de 260. Em outras palavras, cinco ciclos de 52 anos sazonais conformam um grande ciclo de 260 anos sazonais, o qual, por sua vez, pode ser subdividido em 365 ciclos do tonalpohualli.
} 
do Enlace dos Anos, ou Fogo Novo, momento muito celebrado e importante para a visão de mundo nahua e sua concepção de história, pois acreditava-se que em um desses finais de ciclos o mundo voltaria a sofrer cataclismos que poderiam marcar o final de mais uma era ou idade.

É possível que alguns povos setentrionais que migraram para o México Central, entre eles os nahuas, já utilizassem essa conta calendária antes de suas migrações. Embora não se possua nenhuma prova material direta de sua utilização em tempos pré-migracionais, creio que podemos fazer essa inferência a partir do fato de que diversos livros cosmogônicos e de anais de distintos grupos nahuas e chichimecas possuem uma abrangência temporal, uma continuidade narrativa e uma coerência de dados e datas que dificilmente poderia ser resultado apenas de elaborações posteriores à entrada desses grupos na região mesoamericana.

Parece-me muito mais provável que esses grupos setentrionais possuíssem, desde tempos pré-migracionais, indivíduos ou instituições responsáveis pela elaboração de histórias grupais e de explicações acerca das origens do mundo e do homem. E que tais indivíduos ou instituições se serviam de parte do sistema calendário mesoamericano ou de alguma conta calendária similar, que pôde ser transposta ao sistema mesoamericano. Tal hipótese é reforçada pelo fato de que esses grupos compartilhavam uma série de outros traços culturais com os povos mesoamericanos - como por exemplo as concepções cosmográficas -, com os quais mantinham também ativas relações comerciais. ${ }^{21}$

É claro que depois das migrações e da posição de destaque que alguns desses povos setentrionais conseguiram entre os antigos povos mesoamericanos, como aconteceu, por exemplo, com os mexicas, tais histórias e cosmogonias foram re-elaboradas de acordo com as novas demandas e as posições políticas ocupadas dentro das intricadas redes de poder e de alianças. No caso dos mexicas, são os relatos desse período pós-migracional e de hegemonia

\footnotetext{
${ }^{21}$ No entanto, existe uma polêmica sobre a origem dos grupos nahuas. Na verdade, não temos certeza se vieram de fora da Mesoamérica, de dentro ou se regressaram a ela. De acordo com suas próprias fontes, os nahuas seriam chichimecas - denominação geral dada aos coletores-caçadores que habitavam ao norte da Mesoamérica - que migraram. Mas esse discurso pode ser parte de uma estratégia política que reivindicava essa origem - valorizada por sua valentia e bravura guerreiras - para justificar os domínios políticos e tributários sobre outros povos.
} 
política que chegaram até nós por meio de códices pictoglíficos, textos alfabéticos ou obras híbridas do Período Colonial e que expressam a produção da tradição histórica mexica durante os séculos XV e XVI. ${ }^{22}$

O Códice Vaticano A (1996) é um bom exemplo para entendermos, de modo mais concreto, as afirmações feitas acima acerca da tradição histórica nahua e do uso da conta dos anos como elemento organizador das narrativas acerca do passado. Nesse códice, temos uma grande seção que se constitui como um livro de anais, em nahuatl xiuhamatl. Esses anais narram a história da migração mexica desde a passagem por Chicomoztoc, passam pelo estabelecimento e fundação de México-Tenochtitlan e chegam até a época da conquista e princípios da colonização castelhana. Em outras palavras, temos nesse códice uma seqüência narrativa de quase quatrocentos anos, na qual podemos observar claramente que a conta dos anos sazonais, marcada pela sequiência ininterrupta dos glifos de todos esses anos, possui uma função muito específica: fornecer uma espécie de lógica organizacional sobre a qual eram inseridos os registros pictoglíficos dos eventos.

Curiosamente, mas talvez sintomaticamente, esses anais terminam com umas quantas páginas quase em branco (pp. 94v-96v), nas quais temos apenas os glifos da conta dos anos. Em verdade, não sabemos se as páginas ficaram sem os registros pictoglíficos dos eventos que corresponderiam aos anos marcados ou se os glifos da conta dos anos foram pintados antes dos anos que estão sendo marcados, como uma espécie de estrutura prévia à espera de uma seleção, de uma combinação e de uma construção de eventos que seriam aí encaixados. A confirmação da segunda hipótese reforçaria a posição estrutural que estou atribuindo à conta dos anos para a organização das narrativas históricas nahuas.

No caso dos Anales de Cuauhtitlan (1945), texto alfabético produzido em meados do século XVI e cujos autores provavelmente procediam de Cuauhtitlan, cidade de origem nahua e vizinha de México-Tenochtitlan, também podemos perceber o uso da conta dos anos como elemento organizador de uma narrativa temporalmente muito ampla. O texto narra a história dos grupos chichimecas,

\footnotetext{
${ }^{22}$ Vale lembrar que se as explicações acerca do passado cumprem funções ideológicas, como por exemplo a legitimação do poder político de um grupo, necessitam de uma ampla aceitação. Desse modo, é mais eficaz que as novas explicações históricas não se produzam a partir de uma ruptura total com as antigas, mas sim a partir re-elaborações, continuidades ou rupturas aparentes.
} 
principalmente dos mexicas e dos cuauhtitlanenses, desde princípios do século VII d.C. até princípios do século XVI, e apresenta claros indícios de ter tido a antigos livros pictoglíficos de anais como base de sua confecção.

Um desses indícios é a própria maneira de utilização da conta dos anos sazonais, que funciona no tex to como uma espécie de fio condutor que estrutura uma narrativa cujos eventos se dividem e se distribuem, de modo desigual, ao longo das partes dessa conta, isto é, ao longo dos anos do xiuhmolpilli. Vale notar que os nomes de todos os anos são citados de forma completa e ininterrupta por quase novecentos anos, mesmo que durante uma grande série de anos não haja eventos narrados. Esse tipo de emprego da conta dos anos é em tudo semelhante ao que possuía nos anais pictoglíficos, como vimos no caso do Códice Vaticano A, nos quais o xiuhmolpilli também aparecia de forma contínua e ininterrupta, suportando e estruturando o registro pictoglífico dos eventos e das personagens que se distribuíam de forma desigual em seu decorrer.

Tanto no caso dos anais pictoglíficos do Códice Vaticano A como no caso do texto alfabético dos Anales de Cuauhtitlan, creio que podemos perceber claramente que não há nenhum outro tipo de divisão interna ou de elemento 170 estruturante da narrativa a não ser a ininterrupta presença da conta dos anos sazonais, a qual, no caso do Códice Vaticano A, segue marcada mesmo quando já não há eventos registrados. Desse modo, creio que é lícito propor que a presença da conta dos anos sazonais era parte integrante da explicação histórica da tradição nahua e, portanto, parte também da própria percepção de passado. Dito de outro modo, para a tradição histórica nahua, narrar o que aconteceu implicava em localizar temporalmente os eventos em uma conta anual que possuía duas dimensões muito claras e distintas: a sincrônica e a diacrônica.

A sincronia provinha do fato de que os anos sazonais, como vimos anteriormente, se repetiam a cada 52 anos e, junto com eles, suas qualidades. Sendo assim, registrar o que aconteceu nos anos passados era uma forma de se conhecer essas tais qualidades, que regiam os aconteceres, e, desse modo, conhecer relativamente o que iria ocorrer nos anos presentes ou futuros. É a famosa relação entre história e profecia que existe em todas as tradições históricas mesoamericanas e que encontra-se presente sobretudo nos livros maias conhecidos como chilames. ${ }^{23}$ Mas, ao mesmo tempo, seja nos textos pictoglí-

\footnotetext{
${ }^{23}$ Dentre os inúmeros chilames, o mais conhecido é o Chilam Balam de Chumayel (Libro de Chilam Balam de Chumayel 2001).
} 
ficos ou nos alfabéticos, esses ciclos estão dispostos de maneira sucessiva e são acompanhados por eventos também sucessivos - como, por exemplo, a ascensão e morte de um soberano -, fato que garante o inequívoco e preciso registro da diacronia.

O sistema calendário nahua, e mesoamericano em geral, também possuía uma estreita relação com a concepção cosmográfica. Para os mesoamericanos, o espaço dividia-se, verticalmente, em um série de níveis celestes e inframundanos e, horizontalmente, em quatro rumos ou direções e um centro. Todas as subdivisões dos ciclos calendários que compunham o sistema mesoamericano estavam relacionadas, principalmente, com as quatro direções do mundo horizontal. Desse modo, as trezenas que compunham o tonalpohualli se relacionavam sucessivamente com os rumos do universo, começando pelo oriente, passando depois pelo norte, pelo ocidente e chegando ao sul, girando pelo horizonte no sentido contrário ao dos ponteiros do relógio. Esse mesmo movimento do tempo pelas direções do universo era atribuído ao ciclo dos anos sazonais, no qual cada ano se relacionava com uma das direções.

Todas essas direções, além dos próprios números e signos que marcavam os dias e anos, eram portadoras de qualidades e características específicas e que assim carregavam o tempo com influências e qualidades distintas, conforme sua direção de procedência. Desse modo, para a tradição histórica nahua, o tempo não era uma entidade absoluta, apenas quantificável e desprovida de qualidades inerentes, mas algo que trazia sempre sua própria carga de destino, seu tonalli, a qual deveria ser entendida para que o homem pudesse, no caso de um tempo propício, obrar em consonância ou, no caso de uma carga adversa, tentar reverter ou anular seus efeitos.

Essa mesma forma de localização temporal também encontra-se presente nos relevos em pedra e outros monumentos, onde é marcada por meio do emprego dos mesmos glifos calendários que estão nos códices pictoglíficos. ${ }^{24} \mathrm{O}$ problema é que na maioria dos relevos e dos monumentos temos apenas uma data e não toda uma longa sequiência do xiuhmolpilli, fato que por vezes gera incertezas na determinação dessa data dentro da seqüência de ciclos de anos

\footnotetext{
${ }^{24}$ Como exemplo, poderíamos citar a famosa Pedra do Sol ou a lápide de inauguração do Templo Maior, ambas na Sala Mexica do Museu Nacional de Antropologia, México DF, que trazem, respectivamente, as datas 13 acatl e 8 acatl, correspondentes a 1479 e 1487 .
} 
sazonais, ou seja, muitas vezes não sabemos se tal data se refere a um ano "x", ou ao ano "x" menos 52 anos, ou ainda ao ano "x"mais 52 anos e assim por diante. No entanto, não devemos nos esquecer que isso não deveria ser um problema para os contemporâneos dessas inscrições e monumentos, que certamente possuíam uma série de outros referenciais externos a tais inscrições e monumentos, os quais permitiam localizar tais datas de forma muito precisa entre os diversos e sucessivos ciclos do xiuhmolpilli, fazendo assim que a dimensão diacrônica dessas datas estivesse assegurada.

Esse mesmo sistema de cômputo temporal também foi utilizado para a elaboração de explicações que versavam sobre um passado muito mais distante, no qual tiveram origem os deuses, o mundo e os homens. Os nahuas, assim como todos os grupos considerados mesoamericanos, explicavam esse distante passado dividindo-o em diversas idades ou sóis, nos quais as atuações dos deuses eram centrais para o desabrochar e o declinar de cada um deles, os quais, em geral, terminavam por grandes cataclismos. Vale notar que esses inícios e finais de idades não eram totais, ou seja, cada idade possuía elementos que se transformavam e continuavam existindo na outra, gerando uma espécie

172 de aperfeiçoamento do mundo, dos homens e de seus alimentos vegetais, aperfeiçoamento esse que culminou na idade e humanidade atuais. Essa humanidade seria, dependendo da versão, a quarta ou quinta e se caracterizaria pela utilização do milho como alimento por excelência.

O que nos interessa aqui é o fato de que os ciclos de 52 anos serviam tanto para contabilizar as explicações acerca do passado mais distante como do passado mais recente. Creio que isso reforça a hipótese de que o sistema calendário - com suas dimensões sincrônica e diacrônica - desempenhava um papel central para a percepção de passado, distante ou recente, e para a construção de narrativas explicativas por parte da tradição histórica nahua. Tal fato nos indica também que para os nahuas inexistia uma distinção qualitativa ou uma ruptura temporal entre a percepção desses dois tipos de passado.

Apesar dessa continuidade estrutural-calendária entre as narrativas acerca do passado mais distante e mais recente, havia uma importante distinção entre as duas modalidades de relato. No caso das narrativas acerca das idades do mundo, predominava uma grande síntese, ou seja, cada idade era narrada como um todo, no qual se destacavam as ações divinas de criação e destruição, o nome da idade em questão, o tipo de homem que existia, o cataclismo que a encerrou e as mutações pelas quais passaram os homens e outros animais, além, é claro, de sua duração, contabilizada em anos sazonais. ${ }^{25}$ 
De modo geral, depois de narrar essas quatro ou cinco idades, por vezes enfatizando e detalhando um pouco mais as explicações acerca do início da humanidade atual, esses textos cosmogônicos e históricos seguem com os episódios que tratam de Tula, de Quetzalcoatl e dos toltecas, quando então os relatos ganham mais detalhes e, em geral, adotam propriamente a forma de anais, forma essa que continua na narrativa dos eventos mais recentes, como as migrações e os estabelecimentos dos altepeme nahuas na região central do México. Talvez isso indique a existência de uma concatenação narrativa típica da tradição histórica nahua, a qual encaixava a história mais recente dentro de uma sequiência cosmogônica marcada pela existência das diversas idades ou sóis anteriores. Em outras palavras, talvez essa localização da história grupal dentro de um marco temporal mais amplo, fornecido justamente pelas chamadas narrativas cosmogônicas, fosse parte integrante dessa tradição histórica. ${ }^{26}$

No entanto, a existência dessa concatenação dos relatos cosmogônicos e históricos não é uma unanimidade entre os estudiosos. ${ }^{27}$ Muitos afirmam que as histórias indígenas pré-hispânicas caracterizavam-se pela centralidade do altepetl e que essas histórias mais gerais, produzidas no Período Colonial, seriam o resultado da influência das histórias universais cristãs, as quais levaram os indígenas a reunir em textos únicos as histórias locais e as narrativas cosmogônicas, construindo assim uma estrutura mais próxima dos textos do Velho Testamento, sobretudo do Pentateuco. ${ }^{28}$

E essa centralidade do altepetl nas narrativas oriundas das tradições históricas nahuas é, justamente, a próxima característica a ser tratada.

\footnotetext{
${ }^{25}$ De acordo com o texto da Historia de los mexicanos por sus pinturas (1996), por exemplo, as idades anteriores à atual duraram, respectivamente, 676 anos (treze ciclos de 52), novamente 676 anos, 364 anos (sete ciclos de 52) e 312 anos (6 ciclos de 52). Tratamos desse tema em detalhes em uma outra ocasião (Santos 2002).

${ }^{26}$ Essa estrutura narrativa pode ser observada nos seguintes textos alfabéticos e códices coloniais nahuas: Anales de Cuauhtitlan (1945), Leyenda de los soles (1945), Historia de los mexicanos por sus pinturas (1996) e Códice Vaticano A (1996). Tal estrutura pode ser observada também no texto do Popol Vuhl (1996), que narra a história grupal dos quichés depois da cosmogonia, e nas estelas maias, que localizavam temporalmente os feitos recentes, por meio da conta longa, a partir de uma data inicial (13 ou 14 de agosto de 3113 a.C.), a qual marcaria justamente o início da atual idade.

${ }^{27}$ Uma de suas principias defesas encontra-se em Brotherston 1997.

${ }^{28}$ Entre esses estudiosos, podemos destacar Navarrete Linares 2000.
} 
A maior parte dos escritos nahuas conhecidos - sejam pictoglíficos tradicionais, pictoglíficos adaptados às demandas coloniais ou ainda alfabéticos são anais que possuem como temas centrais a história de unidades políticas independentes, conhecidas como altepetl. Tal centralidade também é confirmada pela concepção cosmográfica reinante na Mesoamérica, na qual o espaço se dividia, verticalmente, em um série de níveis celestes e inframundanos e, horizontalmente, em quatro rumos ou direções e um centro, ocupado justamente por cada altepetl, que se concebia, portanto, como o umbigo do mundo.

Como vimos acima, em algumas narrativas alfabéticas indígenas coloniais, esses anais aparecem depois de uma seção que abordou a cosmogonia e suas várias criações e destruições sobrepostas, apresentando as histórias locais, ou seja, a história de determinados grupos e seus altepeme, como um capítulo inserido em histórias mais amplas, as quais abarcariam desde as origens do mundo e do homem, passariam pelas histórias tolteca e das migrações de cada grupo e chegariam até o passado imediatamente anterior à produção de tais narrativas. No entanto, muitos dos anais pictoglíficos nahuas, como por exemplo a Tira de la peregrinación, também chamada de Códice Boturini (1975),

174 iniciam-se simplesmente com a história migracional do grupo ou, no máximo, com a história tolteca, não contando assim com a presença de uma seção dedicada às histórias cosmogônicas.

Isso pesa a favor da hipótese de que as narrativas que possuem a tal concatenação - cosmogonia, história tolteca e histórias locais - sejam, na verdade, uma tentativa indígena-colonial de adaptar as explicações históricas e cosmogônicas nahuas tradicionais a uma estrutura mais próxima das histórias universais cristãs. Talvez tais relatos existissem de forma mais ou menos independente e, em princípios dos tempos coloniais, tenham sido conectados pelos informantes, alunos indígenas e religiosos dos colégios missionários - principalmente franciscanos - para que tivessem formatos similares aos das histórias cristãs de então.

De qualquer modo, a maioria dos textos, pictoglíficos ou alfabéticos, produzidos pelos grupos nahuas que se estabeleceram no Vale do México apresentam uma história mais curta em termos temporais e caracterizada pela atenção central dedicada aos processos de migração, à história tolteca e ao estabelecimento definitivo dos altepeme e suas linhagens de governantes. Tais linhagens, quase que invariavelmente, relacionavam-se com os toltecas, fato que era evocado como fonte de legitimidade para os papéis que cada nova entidade política da região desejava ocupar: herdeiros dos toltecas no controle político e comercial depois da decadência de Tula, por volta do século XII. 
A comparação entre tais textos mostra-nos a existência de enormes semelhanças estruturais e narrativas entre as histórias particulares de cada altepetl. Uma dessas semelhanças reside na existência de fórmulas narrativas comuns ao se tratar de eventos-padrão, como, por exemplo, a partida da terra original, o estabelecimento definitivo do altepetl, suas alianças e conflitos (Navarrete Linares 2000). Tais similitudes poderiam ser fruto de fortes contatos entre as tradições históricas dos diversos grupos nahuas ou resultado da derivação de todas essas narrativas de um modelo histórico comum, talvez de origem tolteca ou ainda teotihuacana. Além disso, tais similitudes possuíam importantes funções políticas, pois é sabido que os anais históricos dos altepeme nahuas desempenhavam a função de legitimar a ocupação de determinados territórios e o estabelecimento de fronteiras territoriais e políticas em pleitos inter-grupais, tarefa para a qual era conveniente utilizar-se de uma linguagem e de uma estrutura reconhecida de forma universal. Em outras palavras, os anais deveriam ser uma voz particular que defendesse os interesse do altepetl, mas uma voz particular que compartilhasse elementos reconhecíveis e aceitos pelas tradições históricas vizinhas (Navarrete Linares 2000).

Por outro lado, dentro do altepetl, os anais também funcionavam como uma espécie de atestado de legitimidade para a posição ocupada pelas elites dirigentes diante dos demais grupos sociais, pois registrava como seus antepassados, sangüíneos ou funcionais, eram os responsáveis pela condução das migrações, pela fundação do próprio altepetl e pelas conquistas dos territórios e alianças. Devido a essas funções legitimadoras, as instituições e pessoas responsáveis pela produção dos anais encontravam-se no interior dos grupos governantes ou, pelo menos, relacionavam-se de forma muito estreita com eles. Prova disso é que seus temas mais comuns eram as linhagens de pipiltin, as mudanças de governantes e os eventos que afetavam o altepetl como corporação, como por exemplo as migrações, as fundações, as guerras, os conflitos dinásticos e alguns fenômenos naturais. ${ }^{29}$

\footnotetext{
${ }^{29}$ É muito comum que os anais nahuas registrem os terremotos e os fenômenos celestes menos freqüentes, como os eclipses, as passagens de cometas ou a queda de meteoros, fenômenos para os quais existiam glifos específicos. Esses fenômenos poderiam ser interpretados como prenúncios de importantes eventos. Novamente temos a relação entre história e profecia: o passado poderia contribuir para revelar o futuro ou explicar o presente.
} 
Essa estreita relação entre elites governantes e tradição histórica chegou, inclusive, a se institucionalizar entre os mexicas por meio do calmecac, espécie de centro de formação freqüentado pelos jovens descendentes dos grupos governantes e sacerdotais. ${ }^{30}$ Nessa instituição, eram produzidas e transmitidas - por meio de códices pictoglíficos e da oralidade ${ }^{31}$ - as explicações cosmogônicas e históricas, as quais inseriam-se em meio de uma série de outros saberes como, por exemplo, a arte da guerra e do sacerdócio.

Como conseqüência dessa dupla função legitimadora desempenhada pelos anais das tradições históricas nahuas, cada altepetl ou grupo político procurava criar versões históricas mais vantajosas para si. O resultado é que temos assim uma verdadeira polifonia de versões no que diz respeito às etapas mais recentes da história, principalmente quando os temas são o estabelecimento territorial, as conquistas e expansões, o estabelecimento das elites dirigentes e as alianças com altepeme vizinhos (Navarrete Linares 2000).

No entanto, no que diz respeito às etapas anteriores, que tratam da cosmogonia ou da história tolteca, parece haver uma concordância maior entre as distintas vozes, principalmente quando se trata de estabelecer os toltecas 176 como antecessores das linhagens governantes ou de situar a criação da humanidade atual em Teotihuacan. Essas coincidências reforçam a hipótese lançada mais acima, isto é, que as diversas tradições históricas possuíam muitos contatos ou baseavam-se em tradições históricas anteriores, talvez de origens toltecas ou teotihuacanas.

É esse tipo de tradição histórica nahua que entrará em contato e se confrontará com os castelhanos e com a tradição histórica cristã no século XVI. Veremos os resultados desse encontro-confronto depois de caracterizarmos as tradições históricas incas.

\footnotetext{
${ }^{30}$ Inclusive, o discurso dos sábios e anciãos poderia ser chamado de calmecatlahtolli, sendo que tlahtolli significa discurso, palavra, história ou relato.

${ }^{31}$ A relação entre os escritos pictoglíficos e a oralidade não era de equivalência restrita e direta. A recitação oral, que ocorria em ocasiões especiais e determinadas, interpretava e se expandia a partir dos escritos que, por sua vez, traziam elementos que estavam além das palavras faladas e que permaneciam inalterados ao longo do tempo. Ambos eram partes de um sistema maior de comunicação (Lockhart 1992).
} 


\section{B - Incas e Andes}

Como apontamos acima, as tradições históricas incas de tempos pré-hispânicos, e andinas em geral, são bem menos conhecidas do que as mesoamericanas. Tal deficiência deve-se, principalmente, à escassez de fontes documentais produzidas por tais tradições, em tempos pré-hispânicos ou coloniais, o que talvez relacione-se com o papel preponderante que era desempenhado pelas narrativas orais e por formas de registro muito distintas das que tradicionalmente reconhecemos como tais, como por exemplo os ceques. ${ }^{32}$ Soma-se a isso, a nossa incapacidade de entender completamente os sentidos que eram veiculados por fontes como os quipus, os pallares ou os tocapus. ${ }^{33}$

Devido a tal deficiência, recorreremos a dois campos de estudo que podem nos proporcionar, de forma indireta, algumas informações e características das tradições históricas incas.

Um desses campos é o que trata da visão de mundo andina, cuja importância reside no fato de que nela, certamente, estão os marcos teóricos e conceituais dentro dos quais as tradições incas operavam e construíam suas explicações sobre o passado. Tais estudos utilizam-se, além das fontes materiais e escritas coloniais, dos trabalhos antropológicos realizados no século XX, os quais demonstram a vigorosa continuidade das tradições orais andinas, responsáveis pela manutenção de relatos muito semelhantes aos poucos que foram transcritos no Período Colonial. O outro campo é composto pelos estudos históricos e literários que se dedicam às crônicas coloniais que trataram da história e dos costumes andinos, as quais contaram em suas produções com a participação de membros da sociedade inca ou de indivíduos que transitavam entre os dois mundos, como por exemplo Guamán Poma de Ayala.

\footnotetext{
${ }^{32}$ Os ceques eram linhas ou caminhos demarcados na paisagem por meio das guacas, objetos ou lugares sagrados, muitos dos quais relacionados com os antepassados. Dessa forma, os ceques eram um meio de se fixar ou relacionar a lembrança dos antepassados, e dos acontecimentos a eles vinculados, com a geografia local. Veremos que ao longo dos ceques eram proferidos discursos e encenados episódios sobre o passado.

${ }^{33}$ Além dos famosos quipus, cuja parte da polêmica foi exposta anteriormente, existe também uma discussão acerca dos significados dos pallares, conjunto de desenhos e signos muito freqüentes na cerâmica mochica, e dos tocapus, desenhos e motivos geométricos utilizados nos tecidos das vestimentas, principalmente dos grupos sociais hierarquicamente superiores nas sociedades andinas (Millones 1987: 73-74).
} 
Tomando por base esses estudos, apresentaremos algumas concepções da visão de mundo andina e inca que seriam fundamentais para a construção de explicações acerca do passado, como por exemplo as concepções de espaço, tempo e acontecimento. ${ }^{34}$ Depois, analisaremos algumas textos coloniais que tratam do problema da utilização dos quipus.

Sabemos que no caso dos incas, e povos andinos em geral, predominava uma organização dual do espaço, baseada na concepção de verticalidade e que tendia a dividir o mundo entre acima e abaixo. Talvez a importância dessa divisão relacione-se com a enorme valorização das distâncias verticais nos Andes, responsáveis pelos enormes contrastes ecológicos entre a costa e a montanha, entre as diversas altitudes de montanha e entre essas diversas altitudes e a planície da Amazônia. Desse modo, era fundamental para a população de qualquer região andina estabelecer relações - baseadas no princípio da reciprocidade ou manay de escambo ou comércio com outras populações, ou ainda possuir territórios e enviar colonizadores, chamados de mitmag, a regiões de outras altitudes e, portanto, com outros meios ecológicos (Stern 1986: 25-32).

A indispensabilidade das relações entre as populações de diversas altitudes

178 talvez tenha se formalizado intelectualmente e se explicitado por meio da concepção de uma separação fundamental entre o acima, ou hanan, conceito que se traduz por vida, ordem e luz, e o abaixo, ou hurin, traduzível por morte, desordem e trevas. Vale notar que não se tratava de uma divisão do mundo em categorias binárias, agonísticas e essencialmente distintas, mas sim de uma polaridade complementar dentro da qual o mundo e seus seres transitavam constantemente de um lado a outro. Por exemplo, a polaridade morte-vida era vista como uma longa transição entre dois estágios: do macio-mole para o áspero-duro. Assim, o momento da morte em si não marcava uma divisão binária entre dois estados completa e essencialmente diferentes, mas sim um passo a mais no longo processo que possuía em seus extremos polares o macio e o mole de um lado, características fortemente presentes nos seres jovens, e o

\footnotetext{
${ }^{34}$ Vale frisar que os incas, assim como os nahuas, eram integrantes de uma região cultural geograficamente muito ampla e historicamente muito antiga, à qual podemos chamar de mundo andino ou simplesmente Andes. Desse modo, sua visão de mundo e suas explicações acerca do passado devem ser entendidas como parte de uma tradição de pensamento muito mais ampla, da qual os incas eram partícipes ativos, mas não seus únicos criadores ou portadores.
} 
duro e o áspero em outro, características predominante nos seres velhos e depois no cadáver, no esqueleto e, por fim, nas pedras, que eram vistas como os antepassados mortos em um estágio posterior (Fraser 2002). Desse modo, poderíamos dizer que no mundo andino os homens começavam a morrer antes da morte e continuavam a morrer depois dela.

Quando essa concepção era aplicada à geografia, gerava uma divisão do espaço em pares de opostos que poderiam abranger, de uma só vez, toda a região andina e, simultaneamente, suas micro regiões. Em outras palavras, poderíamos pensar na costa e na montanha como, respectivamente, hurin e hanan; no entanto, cada uma dessas partes, por exemplo a montanha, possuía também suas subdivisões internas entre acima e abaixo (Montoya Rojas 1998).

Essa divisão do espaço e dos seres entre hanan e hurin $^{35}$ somava-se a uma outra divisão do mundo horizontal em quatro partes e um centro, como também acontecia na Mesoamérica com o conceito de quincunce, espécie de divisão do mundo horizontal como uma flor de quatro pétalas e um centro. Essa concepção foi aplicada pelos incas na organização política e tributária das regiões dominadas, chamadas em sua totalidade de Tahuantinsuyu e que se dividiam em: 1 - Antisuyu, correspondente ao norte, região quente e úmida e caracterizada pela floresta amazônica; 2 - Cuntisuyu, correspondente ao sul, região quente e seca e caracterizada pela costa do oceano Pacífico; 3 - Chinchasuyu, correspondente ao oeste, região úmida e fria; 4 - Collasuyu, correspondente ao leste, região seca e fria. Cuzco era o centro dessa grande flor de quatro pétalas e um microcosmos que reproduzia a totalidade dos territórios dominados e do qual, como veremos em detalhe, saiam caminhos que "registravam" sentidos e significados da contagem do tempo e do passado na paisagem: eram os ceques.

De forma muito relacionada a essa concepção espacial, podemos dizer que para os povos andinos o tempo fluía de cima para baixo, de hanan a hurin. Essa concepção de tempo teve uma enorme implicação na concepção de

\footnotetext{
${ }^{35}$ A importância e centralidade dessa divisão polar para o mundo inca, aliada a outros indícios, levou alguns estudiosos a proporem que a existência de dois incas soberanos simultâneos - yanantin ou casal - era, na verdade, a norma. As lutas entre eles serviriam para definir quem seria hanan (vencedor) ou hurin (perdedor). O inca hanan atuaria fora de Cuzco, nas conquistas, nas cobranças de tributos (mita) e no sistema distributivo. $\mathrm{O}$ inca hurin atuaria em Cuzco e estaria mais vinculado ao universo cerimonial. Na maioria dos textos e crônicas coloniais teria havido uma transformação desse poder dual em genealogias de monarcas que se sucediam (Pease 1995).
} 
passado e de história desenvolvida pelos andinos. Segundo essa concepção, os homens nascem solares e suaves e se tornam mais escuros e duros em um processo contínuo para o qual a morte é, ao invés do inverso da vida, a transformação dos homens em pedras, em terra e em montanhas: os homens mortos passavam a povoar o mundo sob outras formas e, desse modo, continuavam sempre presentes. Uma das formas de materialização dessa transformação eram as guacas, seres que faziam com que o passado se tornasse parte do mundo atual e os mortos seguissem vivos abaixo da terra ou ainda como múmias, ou malquis.

Essa presença material, efetiva e latente do passado tornava possível seu retorno. Isso acontecia porque o tempo era responsável pelo movimento do mundo, trazendo as coisas de acima para baixo e as de baixo para acima, causando a inversão dos espaços ocupados pelos seres e provocando assim um pachacuti: momento em que o hurin se tornava hanan e vice-e-versa, uma espécie de cataclismo natural ou social que marcava o momento de transição para uma nova ordem de coisas.

O termo pachacuti parece ter tido sua origem a partir do nome de Pachacuti Inca Yupanqui, soberano inca que viveu entre 1438 e 1471 e que se tornou muito conhecido e respeitado por ter tomado o poder de seu pai, a quem acusava de ser muito tolerante com os inimigos, e por ter conseguido derrotar os changas, principal obstáculo no processo de expansão inca. A conquista dos changas teria ocorrido com a ajuda das pedras - tidas como antepassados que ressuscitaram e se tornaram guerreiros. Desse modo, podemos ver como essa concepção era fundamental para a tradição histórica inca explicar suas próprias conquistas e, particularmente, o momento a partir do qual começaram a se posicionar como os mais importantes senhores dos Andes e possuidores de um grande aparato estatal, ao qual, certamente, a tradição histórica estava incorporada. Veremos mais adiante que esse mesmo conceito foi utilizado para explicar a conquista castelhana, tida como um pachacuti a partir do qual o mundo se colocou de cabeça para baixo.

Para completar essa estreita relação entre tempo e espaço ${ }^{36}$, parece que os incas utilizavam marcas na paisagem para contar o tempo e explicar o pas-

\footnotetext{
${ }^{36}$ As concepções de tempo e de espaço de uma determinada sociedade relacionam-se de modo muito estreito, chegando a formar uma verdadeira unidade no processo de apreensão e de explicação da realidade. Essa unidade tem sido denominada de cronotopo, categoria utilizada analiticamente nos estudos de produções narrativas e literárias, o que a torna virtualmente aplicável também aos estudos históricos que utilizam textos e crôni-
} 
sado. Os dias que compunham o ano solar, chamado de guata, eram contados com ceques que saíam de Cuzco e iam em direção às distintas posições do nascer do Sol entre um e outro solstício. Como citamos anteriormente, nos ceques a tradição histórica inca registrava o passado com guacas, que poderiam ser altares, tumbas ou simplesmente pedras, a partir das quais os acontecimentos eram narrados. Trata-se de uma forma de registro que se dava em uma geografia acrescida de intervenções humanas e que contava com o funcionamento conjunto de uma tradição oral. Além disso, ocorriam grandes encenações nessa paisagem historicizada que, segundo o cronista inca colonial Juan Santa Cruz Pachacuti, desde os tempos de Pachacuti Inca Yupanqui, tratavam dos feitos e conquistas dos soberanos incas. ${ }^{37}$

Além disso é muito conhecido o fato de que os soberanos incas, e também muitas outras pessoas de distintos níveis sociais, eram mumificados e continuavam a ocupar seus palácios ou moradas. A concepção que estava por trás dessa prática era a de que os mortos, e também o passado, continuavam presentes sob outra forma, continuavam no mundo de hurin (abaixo) sob a forma de pedras ou de malquis (múmias) e, potencialmente, aptos para um retorno quando o mundo passasse por um pachacuti. ${ }^{38}$

Essa concepção do passado como algo que continuava a existir aqui e agora parece ter minorado a necessidade de utilização de uma ampla contagem dos anos. Há uma polêmica acerca da existência ou não de tal contagem no mundo andino, mas parece que de todos os modos ela não teve um papel de destaque na organização da memória histórica entre os incas. Vale ressaltar que não estamos falando de uma limitação técnica ou conceitual, mas sim do papel que a tradição histórica inca dava para a contagem do tempo. É sabido que os povos andinos utilizavam várias formas de cômputo do tempo, como por exemplo o

cas como fontes. O conceito de cronotopo ou tempo-espaço foi cunhado na Teoria da Relatividade para estabelecer o estreito vínculo entre essas duas dimensões, presentes na realidade e na percepção humana do mundo. Depois, Mikhail Bakhtin aplicou o conceito à literatura e demonstrou a necessidade da existência de uma concepção coerente de tempo-espaço no interior das narrativas literárias, fato que garante e torna possível sua inteligibilidade (Navarrete Linares 2002).

${ }^{37}$ Tal informação aparece na obra em quíchua desse cronista, intitulada Relación de antiguedades deste reyno del Perú e escrita em 1613 (Millones 1987: 140-141).

${ }^{38}$ Em tempos coloniais, os nobres incas aliados aos castelhanos continuaram a exibir os malquis de seus antepassados em encenações públicas. 
próprio ano solar, os ciclos de nove meses lunares e as semanas de dez dias, mas parece que elas não eram utilizadas para definir e localizar de modo cronológico-linear os acontecimentos ou mesmo a duração da vida dos indivíduos, a qual era computada por ciclos vitais baseados nas condições físicas e na capacidade para o trabalho.

Esse assunto é tratado por Guamán Poma de Ayala que, sintomaticamente, não descreve as diversas idades da vida em ordem cronológica, ou seja, começando pela infância e terminando com a velhice. Guamán Poma inicia seu relato pela idade considerada mais importante, a de maior potencialidade para o trabalho, isto é, pelo ciclo que vai aproximadamente dos 25 aos 50 anos e que era chamado de auca camayoc, no caso masculino, e auca camayoc uarmi, no caso feminino. Depois, trata das idades posteriores a esse ciclo de forma progressiva e, por fim, das idades anteriores de forma regressiva (Díez Canseco 1985).

É quase inevitável pensar que havia uma relação conceitual na organização e na utilização mnemônica dos ceques - que partiam de Cuzco e que continham suas tumbas, altares, pedras ou guacas - com os quipus e seus diversos tipos de nós. Isso leva-nos de volta ao problema da utilização dos quipus como registros mnemônicos que possuíam dimensões narrativas além das quantitativas.

Como dissemos de início, não possuímos reconhecidas "traduções" ou transliterações coloniais de narrativas supostamente registradas pelos quipus ou veiculadas pela tradição oral quíchua. No entanto, alguns cronistas coloniais afirmam que os informantes indígenas se baseavam em quipus para lhes relatar acerca da história e de outros temas, como por exemplo para se recordar dos pecados durante a confissão. A esse respeito, na obra Nueva Corónica y buen gobierno, Guamán Poma afirma "Que los dichos padres del santo sacramento de la confición mande exsaminar su anima y consencia una semana el dicho penetente aunque sea español y el yndio haga quipo de sus pecados." ${ }^{39}$ Afirma também, em diversas partes de seu relato, que seus informantes tudo sabiam a partir dos quipus e que ele próprio tirou informações deles "pues que en los cordeles supo tanto que me hiciera a fuerza en letra". ${ }^{40}$

\footnotetext{
${ }^{39}$ Apud Montoya Rojas 1998a: 175. Nessa mesma página, Rodrigo Montoya reproduz uma citação de Pérez Bocanegra, de 1631, que reafirmaria essa função dos quipus: "Para este efecto les mandan vayan atando ñdos en sus hilos que llaman Caitu, y son los pecados que les enseñan, los cuales parecen: añadiendo y poniendo en sus nudos otros, que jamás cometieron, mandándoles, y enseñándoles, a que digan es pecado el que no lo es, y al contrario."

${ }^{40}$ Apud Brotherston 1997: 118.
} 
Além disso, parece que os próprios castelhanos perceberam a existência de dimensões não numéricas de registro nos quipus e, assim como no caso dos códices mesoamericanos, promoveram grandes queimas para destruir aquilo que, ao juízo cristão, continha informações acerca da idolatria.

Outro argumento a favor de que os quipus possuíam dimensões narrativas é o estudo do caso de um pleito judicial no qual um quipu teria sido apresentado e lido pelos senhores de Hatun Xauxa à Audiencia de Los Reyes em 1561. Esse caso confirmaria, no mínimo, que os cordéis do quipu estavam organizados sistematicamente para representar sempre uma mesma seqüência de categorias de seres (homens, batatas, lhamas, sandálias, cerâmicas, carvão, pescado e etc.), distribuídas, por sua vez, em uma outra seqüência cronológica. ${ }^{41}$ Por fim, podemos agregar também o caso relatado por Guamán Poma de Ayala dos famosos mensageiros incas, ou hatun chasqui, que levavam mensagens com quipus, os quais especificariam datas e locais e que são equiparados por esse cronista com as cartas. ${ }^{42}$

Além desses testemunhos que relacionam o uso dos quipus com o registro de informações não numéricas, sabemos, também por relatos do início do Período Colonial, que a formação de um experto em quipus, chamado de quipucamayoc, demorava quatro anos e acontecia em escolas - yacha huasi - no centro do mundo inca, isto é, em Cuzco. Será que para entender apenas as dimensões numéricas dos quipus seria necessário tanto tempo? Será que estes depoimentos são suficientes para afirmamos que os quipus eram uma espécie de escrita? Essa questão nos leva a outro intrincado problema: o que é uma escrita? ${ }^{43}$

\footnotetext{
${ }^{41}$ A afirmação que consta nos autos do pleito judicial é a seguinte: "Los yndios desta tierra tienen cuenta y razon de las cosas que dan a sus señores (...) por quipos que ellos llaman y todo lo que han dado de mucho tiempo atras lo tienen asimismo en sus quipos. E saue este testigo que los dichos sus quipos son muy ciertos e verdaderos porque este testigo muchas y diversas veces ha cotejado algunas cuentas que ha tenido con yndios de las cosas que le han dado e le han debido e les ha dado e ha hallado que los quipos que tienen los dichos yndios eran muy ciertos ..." Tal afirmação teria sido feita por Pedro de Alconchel e foi publicada por Waldemar Espinoza Soriano em "Los huancas aliados de la conquista; tres informaciones inéditas sobre la participación indígena en la conquista del Perú, 1558, 1560 y 1561". in Anales Científicos de la Universidad del Centro 1. Huancayo, 1971, 1972. Apud Murra 1985: 433.

${ }^{42}$ As ilustrações que retratam os hatun chasqui encontram-se nas páginas 350 e 811 da Nueva corónica y buen gobierno (Guamán Poma 1980).

${ }^{43}$ Não se trata de uma questão meramente nominalista, mas sim da utilização analítica do conceito de escrita para a abordagem e a interpretação dos quipus ou outros tipos de registro do pensamento e da fala.
} 
Alguns estudiosos dos quipus andinos (Ascher \& Ascher 1997) e dos códices pictoglíficos mesoamericanos (Brotherston 1997) mostram que considerar como escrita apenas aos sistemas logográficos, isto é, que registram a fala, é uma enorme e preconceituosa redução analítica do mundo ocidental para com outros sistemas de representação do pensamento e da fala. Tal redução estaria baseada no pressuposto de que a escrita logográfica, seja ela fonética ou silábica, é o estágio mais avançado de uma suposta evolução universal dos sistemas de representação do pensamento e da fala, ao qual uns poucos povos eleitos teriam chegado. Essa suposta evolução teria começado com as pinturas e os sistemas ideográficos no Oriente e Oriente Médio e chegado ao seu mais alto grau com o alfabeto fenício e grego, caracterizado pela utilização de signos abstratos, que possuem uma relação convencional de correspondência quase que exclusiva com a fala. ${ }^{44}$

De acordo com essa visão, poderíamos estudar e classificar evolutivamente os sistemas não alfabéticos por aproximações ou carências em relação ao sistema alfabético ocidental. Será que agindo desse modo, ou seja, analisando os sistemas de registros por suas supostas carências e de forma desligada das demandas de 184 suas sociedades produtoras, não deixaremos de entender as especificidades de funcionamento, as lógicas organizadoras, as formas de leitura, as relações específicas com a oralidade e os usos sociais desses outros sistemas?

Para os estudiosos que defendem a ampliação do uso analítico do conceito de escrita, a oralidade não representaria um dos pólos de um binômio agonístico, no qual encontraríamos, no outro extremo, a escrita alfabética. Em todos os sistemas haveria graus de foneticismo que variariam de um para o outro, pois nenhum conjunto de sinais gráficos seria capaz de representar por completo a língua falada, dependendo, em última instância, de uma oralidade paralela e complementar. De acordo com esses autores, o conceito de escrita deveria ser ampliado e entendido como uma forma sistemática de registro, que possui sua própria inteireza, estrutura interna, formato, ordem de funcionamento e de leitura e que é utilizada para representar com regularidade sons ou conceitos por meio de sinais gráficos ou outros artifícios - e que pode se relacionar com a oralidade de formas diversas e em diversos graus.

\footnotetext{
${ }^{44}$ Entre os estudiosos que ainda seguem esse modelo evolucionista no estudo dos sistemas mesoamericanos de escrita, podemos citar Manrique Castañeda 1989.
} 
Será que essa concepção mais ampla de escrita abrangeria o sistema dos quipus? Caso abrangesse, como entender ou ler as informações contidas nos diversos exemplares que chegaram até nós, de tempos pré-hispânicos e coloniais, se não possuímos "traduções” coloniais que explicitem o funcionamento do sistema e se a tradição dos quipucamayocs praticamente já não conta com nenhum representante em nossos dias? ${ }^{45}$ Que importância possuía esse sistema para a tradição histórica inca? Que relação possuía com a tradição oral? São perguntas para as quais ainda não temos muitas respostas, mas sobre as quais vários estudiosos se dedicam atualmente e, certamente, produzirão trabalhos que nos ajudarão a entender, em um futuro muito breve, alguns aspectos mais da tradição histórica inca em tempos pré-hispânicos e coloniais. ${ }^{46}$

Um outro aspecto acerca das tradições históricas incas que merece ser mencionado é sua centralidade e quase exclusividade nas poucas fontes textuais que conhecemos do Período Colonial. Vimos que no caso mesoamericano imperava uma certa polifonia de vozes, que explicavam de modo central a história de cada altepetl. A situação é bem diferente no caso andino, pois as informações contidas nas fontes coloniais provêm, preponderantemente, da tradição histórica inca, que era parte de uma memória oficial a serviço de um recente domínio expansionista sobre uma região com pelo menos 6.000 anos de história. ${ }^{47}$ Podemos aventar duas explicações para esse fenômeno e que não são, necessariamente, excludentes.

Em primeiro lugar, podemos pensar que esse quase monopólio inca da história andina deva-se ao tipo de dominação praticada, caracteristicamente cen-

\footnotetext{
${ }^{45}$ Existem mais de 600 quipus espalhados por coleções públicas e privadas de todo o mundo. A maior delas, cerca de 300 exemplares, encontra-se no Museum für Völkerkunde, em Berlim (Urton 2003: 11).

${ }^{46}$ Vale ressaltar que não se trata de condicionar a existência das tradições históricas incas e andinas a uma forma de registro escrito, mas de perceber que o entendimento das possíveis dimensões narrativas nos quipus abriria novas possibilidades de estudo e de conhecimento dessas tradições.

${ }^{47}$ Vale notar que a antiguidade dos primeiros centros cerimoniais e populacionais na região dos Andes é muito maior do que na Mesoamérica, com datas que variam entre 4000 a.C. e 3500 a.C. na região do lago Titicaca. Além disso, foram descobertas múmias no norte do Chile que datam de 5000 a.C. e que possuem sofisticados tecidos e marcas de trepanação. Veremos adiante que algumas informações acerca das civilizações andinas anteriores e contemporâneas aos incas encontram-se na crônica de Guaman Poma de Ayala, na qual a concepção de que os incas foram os "civilizadores dos Andes" é muito presente.
} 
tralizadora e que submetia os povos conquistados ou aliados a uma estrutura política, econômica e cultural que emanava de seus centros de poder. Entre as práticas que faziam parte dessa estrutura estatal e centralizadora inca estavam: o estabelecimento de centros de controle político que se sobrepunham às elites locais, as quais eram, por vezes, deslocadas para Cuzco e incorporadas à elite inca; o assentamento de etnias estrangeiras nas terras dominadas e o deslocamento de grupos dominados para outras regiões; a construção de palácios e bases de guarnições militares e de armazéns para o controle e a distribuição de víveres. ${ }^{48}$ Talvez a centralização política e a imposição de um aparato estatal tenha desarticulado ou submetido as tradições históricas locais, cujos membros certamente pertenciam às elites locais incorporadas, aliadas ou vencidas. Em suma, as explicações históricas eram parte integrante do processo de legitimação ideológica do domínio inca e deveriam ser controladas ou emanar de seus centros.

Em segundo lugar, podemos pensar que esse monopólio inca da história andina deva-se ao fato de que a grande maioria dos textos coloniais sobre a história local procede dos antigos centros de poder e que, desse modo, contaram em sua produção com informações oriundas da tradição inca ou com a participação de indígenas a

186 ela vinculados. Além disso, havia um outro motivo para que as elites indígenas locais repetissem a versão inca da história andina, pois, como veremos em detalhe a seguir, estabelecer uma relação de descendência com o passado inca poderia funcionar para a obtenção ou a garantia de privilégios, já que o domínio castelhano se consolidou no mundo andino por meio de alianças com a elite inca, ou com o que havia restado dela depois dos conflitos iniciais.

\section{2 - Transformações e continuidades das tradições históricas nahua e inca durante o século XVI e início do século XVII}

Nesta parte, trataremos de caracterizar e analisar comparativamente as transformações e as continuidades pelas quais passaram as tradições históricas nahua e inca diante da conquista e colonização castelhana. Para isso, utilizaremos, sobretudo, as fontes produzidas no início do Período Colonial que trataram da história inca ou nahua como temas centrais e que contaram com a

\footnotetext{
${ }^{48}$ Isso não significa que os modos locais de organização social e de produção eram radicalmente alterados (Stern 1986: 49-53).
} 
participação de membros das tradições históricas nativas. O objetivo central não será proporcionar uma análise minuciosa de cada uma das fontes, mas sim estabelecer algumas características e reflexões gerais acerca de suas produções, usos e consumos, tarefa para a qual nos serviremos também dos estudos historiográficos.

\section{A - 0 impacto da conquista militar}

As conquistas militares dos mundos inca e nahua foram, ao mesmo tempo, processos muito semelhantes mas também muito distintos. Tratemos dessas similitudes e distinções.

Ambos processos contaram com a participação de castelhanos que, a partir de empresas particulares e com a autorização real, buscavam estabelecer domínios subordinados à Coroa de Castela. Em ambos casos, os castelhanos contaram com a participação aliada de grupos indígenas contrários aos domínios inca e mexica. Foi utilizado nos dois casos, sobretudo por parte dos conquistadores e seus aliados, uma violência um tanto quanto inaudita, ou pelo menos pouco usual nos Andes e na Mesoamérica, pois as lutas e matanças se direcionaram não apenas contra os guerreiros mas também contra toda a população. Além disso, as guerras passaram a durar todo o ano e não mais se restringir a determinadas épocas. Em ambos processos, a principal justificativa da conquista foi a suposta idolatria dos povos nativos e a obrigação cristã de levar-lhes o Evangelho, o que resultou na obrigatoriedade da conversão, pelo menos formal, dos povos aliados ou conquistados e na destruição de tudo que, ao juízo cristão, estivesse relacionado com as antigas práticas religiosas: a conquista político-militar era uma empresa inseparável da conversão religiosa, tanto que nas duas regiões podemos observar a participação de clérigos desde os primeiros momentos de contato e confronto.

De acordo com os ideais da Reconquista que regiam a política e a religião ibéricas nesse momento, a vitória militar castelhana e de seus aliados, formalmente convertidos, gerava como consequiência um outro e inevitável passo, isto é, a aceitação das explicações cristãs acerca do passado, do presente e do futuro. A vitória militar era também a vitória do deus cristão e da visão de mundo e de história católica. Essa situação impôs um grande desafio aos membros das elites indígenas, portadores das tradições históricas, durante o Período Colonial: além da sobrevivência física, era necessário encaixar e adaptar as explicações históricas tradicionais à visão de mundo dos vencedores, parte da qual foi 
apropriada rapidamente pelos indígenas, aliados ou derrotados, que se converteram rápida e sinceramente ao cristianismo ou ao que entendiam por tal.

Em outras palavras, não devemos nos esquecer que a posição hierarquicamente superior ocupada pela visão de mundo e de história cristãs não era fruto de um debate epistemológico no qual o cristianismo mostrou-se como a melhor e mais apropriada forma de entender e explicar a história do mundo e do homem. O que houve foi uma vitória militar que garantiu uma posição de comando ao pensamento cristão, posição essa que determinava a direção e o sentido das adaptações e reelaborações: eram as explicações cosmogônicas e históricas nativas que deveriam adequar-se ao modelo cristão e não o contrário. ${ }^{49}$

Porém, isso não significa que os castelhanos ditaram e dirigiram todos os processos de transformação no mundo colonial e que a influência tenha se dado em uma só direção. ${ }^{50}$ Sabemos que as formas de controle político e tributário, a religiosidade e o cotidiano colonial foram determinados, em grande parte,

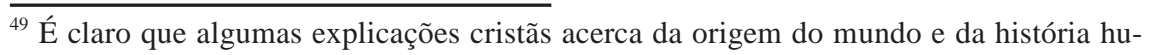
mana foram colocadas em xeque com a certeza de que a América era um "novo mundo", não referido pelos textos bíblicos ou por Aristóteles. Mas isso não significa que as explicações construídas pelos povos americanos acerca do passado tenham sido levadas em conta - pelo menos não explícita ou conscientemente - pelos pensadores que trataram de reformular as tradicionais explicações cristãs. Essa reformulação se deu, sobretudo, a partir do próprio pensamento aristotélico-tomista e de umas poucas e genéricas informações sobre a América. Esse tipo de reformulação pode ser observado na obra do jesuíta José de Acosta (Acosta 1985). Mas essas reformulações - cujos alicerces estavam em ruínas, segundo Descartes em suas Meditações - foram paulatinamente sendo substituídas por explicações construídas fora das universidades cristãs e fundadas em outros princípios. Esse processo é conhecido como Revolução Científica, do qual o Iluminismo pode ser visto como uma continuação. Neles, o pensamento dos povos americanos pode ter desempenhado alguma influência, de forma indireta e implícita.

${ }^{50} \mathrm{O}$ impacto do descobrimento da América e de seus povos sobre a cosmologia cristã é um tema bem estudado. Mas talvez faltem estudos sobre o impacto e a participação das explicações de mundo americanas nas reformulações das explicações cosmogônicas e históricas européias, reformulações essas que caracterizaram a história intelectual da Europa durante toda a Época Moderna, e que culminaram no Iluminismo. Um caminho fecundo de pesquisa poderia ser o mapeamento do percurso das crônicas e textos que incorporaram ou reproduziram explicações e conhecimentos americanos e que chegaram até a Europa principalmente pelos jesuítas nos séculos XVII e XVIII - ou aí foram publicados. Esse seria o passo inicial para tentar entender até que ponto tais explicações poderiam ter sido conhecidas e lidas pelos pensadores europeus modernos e de como estariam presentes em suas obras. Um caso mencionado freqüentemente é o de Montaigne, quem seguramente conhecia algumas idéias cosmogônicas mesoamericanas, comentadas em seus Ensaios. 
pelas tradições indígenas, responsáveis portanto pela instauração de mundos coloniais distintos nas diversas regiões americanas que eram controladas pelo mesmo poderio castelhano. Apesar desse papel central das populações indígenas na construção do mundo colonial, é importante ressaltar que o processo de transformação não foi simétrico entre os dois mundos que se encontravam e se enfrentavam nos Andes e na Mesoamérica. A posição de domínio castelhano e o crescente contingente de europeus que chegava à América permitiu que os estrangeiros criassem e dirigissem uma sociedade viável, que não corria o risco de ser engolida pelas sociedades locais, cujos contingentes populacionais eram cada vez menores devido às enfermidades e maus-tratos (Lockhart 1992).

Desse modo, a progressiva substituição dos aparatos estatais inca e mexica pelo castelhano-cristão, aliada ao processo de conversão religiosa, gerou uma impossibilidade crescente de manutenção e de reprodução das tradições históricas nativas de forma independente dos poderes castelhanos, pois seus membros eram, tradicionalmente, parte dos antigos poderes estabelecidos, que agora encontravam-se, majoritariamente, submetidos ou aliados aos cristãos. Em regiões mais distantes dos centros castelhanos de poder, as tradições nativas mantiveram, por muito tempo, uma relativa autonomia e continuaram a produzir suas próprias explicações acerca do passado, produções essas que inclusive incorporavam os novos e recentes acontecimentos, que envolviam os castelhanos, e se expressavam por meios tradicionais, como os códices pictoglíficos e a tradição oral.

Apesar de todas essas similitudes entre os processos de conquista, houve especificidades significativas e que geraram distintas formas de relação e de pactos entre os antigos poderes locais, nahua e inca, e os novos senhores castelhanos. As especificidades na construção dos contatos - assim como as distintas e prévias visões de mundo nahua e inca - contribuíram para a elaboração de explicações históricas nativas que incorporavam de maneira distinta o fenômeno da conquista e presença castelhanas.

No caso da conquista de México-Tenochtitlan, as alianças prévias seladas por Cortés e Malinche ${ }^{51}$ entre 1519 e 1520 com os altepeme vizinhos e inimigos tiveram um papel fundamental na rápida derrota do centro do poderio mexica,

\footnotetext{
${ }^{51}$ Também conhecida como Malintzin, cujo importante papel nessas negociações é retratado em fontes nativas, como o Lienzo de Tlaxcala.
} 
que ocorreu entre 1520 e 1521. Desde Cempoala, os castelhanos estabeleceram alianças com mais de dez altepeme para a luta contra os mexicas, dentre os quais destacam-se Tlaxcala e Chalco. Calcula-se que o exército que chegou a México-Tenochtitlan em novembro de 1519 contava com cerca de 500 castelhanos e 10.000 indígenas aliados.

Além disso, parece que Moctezuma e parte dos mexicas queriam evitar a guerra e receberam os castelhanos e aliados de forma amistosa para tentar estabelecer um pacto político. Mas talvez a impossibilidade de uma aliança política sem a conversão religiosa deu início aos conflitos, que começaram justamente numa das mais importantes festas religiosas mexica: a festa de Toxcatl, que terminou com o famoso episódio da Matança do Templo Maior e com os castelhanos sitiados. Depois da desesperada fuga para Tlaxcala, conhecida como Noche Triste, sobreviveram apenas um quarto dos castelhanos, que trataram de, entre julho e novembro de 1520, pedir reforços às ilhas do Caribe e recompor e ampliar as alianças locais.

Em novembro desse mesmo ano, castelhanos e aliados reiniciaram uma nova marcha, dominando o Vale de Puebla e todo o sul da Cuenca. Até março de 1521 190 contavam também com aliados ao redor de todo o lago Texcoco, os quais já totalizavam mais de quarenta altepeme. México-Tenochtitlan, liderada agora por Cuauhtemoc, resistiu até agosto de 1521 quando, após a morte de cerca de $80 \%$ da população, os últimos soldados mexicas foram vencidos e consumou-se o domínio dos cerca de 1.000 castelhanos e dos 20.000 indígenas aliados.

Essas alianças dotaram a vitória dos castelhanos de uma certa legitimidade aos olhos da complexa e intricada rede política que regia as relações entre os altepeme mesoamericanos, os quais mantiveram, pelo menos durante as primeiras décadas após a queda de Tenochtitlan, uma certa continuidade de suas autonomias e poderes locais, pois estavam ao lado dos vencedores. Sendo assim, as elites indígenas desses altepeme sentiam-se como parte do regime colonial e não como vítimas dele, fato que garantia uma certa colaboração política. Essas alianças criaram também redes políticas complexas - que opunham, por exemplo, os castelhanos e indígenas aliados aos indígenas inimigos - e garantiram a rápida expansão dos novos senhores de Tenochtitlan em direção a Oaxaca (1524), aos domínios tarascos (1524-1530) e a parte da Guatemala (1524). Veremos, no próximo sub-item, as consequiências dessa rápida conquista e das alianças castelhanas com as elites locais para o funcionamento e o papel das tradições históricas indígenas na nova ordem colonial. 
No caso da conquista dos incas, temos um processo de lutas e conflitos muito mais longo, que vai de 1532, com a prisão de Atahualpa por Pizarro, até 1572, com a morte de Tupac Amaru. Esse longo processo pode ser dividido em três fases (Navarrete Linares 2002).

A primeira fase, de 1532 a 1536, iniciou-se com o famoso episódio da prisão de Atahualpa por Pizarro, em Cajamarca, e pela morte de milhares de incas e de apenas um castelhano. Essa fase teria terminado com a rebelião de Manco Capac, soberano inca nomeado após a morte de Tupac Hualpa, que havia sido nomeado pelos castelhanos após a execução de seu irmão Atahualpa e que morreu em conflitos com grupos fiéis a Huáscar, assassinado enquanto Atahualpa estava preso pelos castelhanos. Vale notar que os castelhanos fundaram Lima já nessa primeira fase da conquista, em 1535, e a fundaram na costa, fato que marcaria o início de uma marcada separação sócio-geográfica entre o mundo castelhano e o indígena que persistiu durante todo o Período Colonial e chegou até a atualidade.

A segunda fase, de 1536 a 1555, caracterizou-se pelo combate à rebelião de Manco Capac por Diego de Almagro, pelo refúgio dos incas em Vilcabamba, por uma série de períodos de guerra e paz e por uma guerra civil entre os castelhanos seguidores de Pizarro e de Almagro. Até esse momento, os povos vizinhos não haviam apoiado os incas contra os espanhóis, pois viam o fim de sua dominação como uma chance de maior autonomia, fato que se tornava real com a crise da rede de caminhos e do aparato estatal inca, responsável pela cobrança dos tributos.

A terceira fase, de 1555 a 1572, foi marcada pela consolidação do poder castelhano, pela chegada do vice-rei Mendoza e dos burocratas após a morte dos conquistadores e pelo início do pesado regime de trabalho ao qual os indígenas foram submetidos nas minas de prata, e que causou inúmeras rebeliões. Essa fase caracterizou-se também pela continuidade da resistência inca desde Vilcabamba, principalmente até 1567, quando Titu Cusi firmou a paz com os castelhanos. Mas após sua morte, em 1571, seu irmão, Tupac Amaru, rebelouse e foi vencido e executado publicamente em Cuzco, em 1572.

O longo processo de conquista castelhana e de resistência inca aliado ao pesado regime de trabalho e de tributos - que transformava a tradicional mita em uma espécie de escravidão - geraram um verdadeiro caos social e econômico que atingiu todas as regiões antes dominadas pelos incas, o que contribuiu para a generalização de um sentimento de rechaço ao poder político e à religião dos castelhanos. Além disso, o número de aliados indígenas que se sentia 
vitorioso com a derrota dos incas era muito menor do que no caso dos mexicas. Veremos que as explicações históricas nativas para a conquista castelhana construídas nessa fase final ainda acreditavam na possibilidade de expulsão total dos castelhanos e na restauração da ordem andina anterior, anterior inclusive aos próprios incas. ${ }^{52}$

No entanto, a progressiva instalação do aparato colonial castelhano após o fim das lutas contra os incas cooptava, cada vez mais, os membros das elites incas derrotadas e os curacas dos mais diversos povoados. Conjuntamente, o crescimento do número de castelhanos mostrava ao mundo andino que estavam ali para ficar. Veremos que esses fatos transformaram as explicações andinas e incas da conquista produzidas nessa fase - fins do século XVI e início do XVII - pelas elites locais aliadas, que passaram a tratar o fenômeno da conquista e da colonização castelhana como algo irreversível. Não se tratava mais de expulsar os castelhanos, mas sim de conseguir um sistema mais justo sob a ótica andina, um sistema que respeitasse os princípios básicos da reciprocidade e da organização social local, garantindo assim os privilégios e poderes subordinados das elites locais, pois reciprocidade, mesmo em tempos pré-hispânicos,

192 não era sinônimo de relações igualitárias.

\section{B - Convivência, resistência e reacomodações}

Depois de findados os processos de conquista militar, caracterizados pela grande intensidade de guerras e matanças e pela imposição final do domínio dos conquistadores e seus aliados indígenas, iniciou-se nas regiões nahua e inca uma outra etapa histórica, caracterizada principalmente pelo traslado e a implantação de instituições castelhanas e por uma certa estabilidade no controle político e econômico. Isso não significa que as revoltas e conflitos armados não continuaram a existir, principalmente no caso dos Andes e das regiões

\footnotetext{
${ }^{52}$ A idéia do retorno de um incarrí, ou inca-rei, que expulsaria os castelhanos e restauraria a antiga ordem no mundo andino, foi criada posteriormente, entre fins do século XVI e início do século XVII, justamente após a execução pública de Tupac Amaru. Essa idéia, que se tornará central para as tradições históricas andinas, caracteriza-se por uma visão idealizada dos tempos incaicos, e sua construção foi fomentada, principalmente, por dois motivos: a maioria das pessoas que havia vivido sob o domínio inca havia morrido e o crescente domínio econômico, tributário, político e religioso dos castelhanos mostrava, cada vez mais, sua face de violência e de exploração.
} 
mesoamericanas ao norte e ao sul do Altiplano Central, sobre as quais os castelhanos e seus aliados procuravam ampliar seus domínios. ${ }^{53}$

E como vimos anteriormente, esse processo de conquista e colonização política, militar e econômica era inseparável do processo de conquista espiritual. Desse modo, as instituições religiosas cristãs, sobretudo igrejas, monastérios e colégios, também foram trasladadas e implantadas nas regiões conquistadas, passando a ser os principais centros de difusão do pensamento histórico e cosmogônico do Velho Mundo.

Durante o século XVI chegaram à região da Nova Espanha quase três mil religiosos e ao Peru cerca de mil e oitocentos (Borges 1983). Foi com esses religiosos cristãos que parte das tradições históricas nahua e inca se defrontaram. Vejamos como isso se deu entre mexicas e incas.

A rápida expansão dos domínios políticos castelhanos e de seus aliados na região central da Mesoamérica e a relativa legitimidade desses novos dominadores em dezenas de altepeme possibilitaram a difusão massiva do cristianismo e de alguns conceitos de sua visão de mundo. Ao mesmo tempo, era fundamental para as elites nahuas - intermediadoras das relações entre os novos senhores castelhanos e a população indígena - incorporar os símbolos políticos e religiosos castelhanos que demonstravam suas posições sociais, como por exemplo as roupas e os escudos de armas. Também era necessário adequar sua história e cosmogonia à história e cosmogonia do deus cristão vitorioso, deus este que, aliás, não era muito afeito à competição com outros deuses ou a outras versões da criação do mundo e da história dos homens.

O resultado dessas reelaborações foram obras muito diversas, que combinaram de maneiras distintas as histórias e explicações cosmogônicas tradicionais com as idéias de origem cristã. No entanto, todas elas possuem em comum o fato de se destinar a dois universos de públicos distintos: os religiosos e mandatários castelhanos e as elites e populações nahuas. A maioria dos autores dessas obras estavam interessados em assegurar para si e para seu grupo as posições e privilégios sociais dentro da nova ordem colonial e, para isso,

\footnotetext{
${ }^{53} \mathrm{Na}$ verdade, é muito difícil estabelecer um limite cronológico entre conquista e colonização que valha para toda e Mesoamérica e Andes. Cada região e povo viveu esses momentos em épocas distintas. Sabemos que em alguns casos, a invasão territorial e a conquista militar foram processos que só se consumaram nos séculos XIX e XX. Sendo assim, a divisão que estamos estabelecendo entre conquista militar e colonização serve apenas para os dois casos estudados, isto é, nahuas do Altiplano Central e incas.
} 
necessitavam dialogar com o mundo castelhano, por um lado, e com o indígena por outro, pois somente sendo entendidos e legitimados pelos dois é que poderiam manter sua privilegiada posição de elite intermediária.

Algumas das mais importantes obras que se encaixariam nessa tipologia foram escritas por Fernando Alvarado Tezozomoc, Domingo Francisco de San Antón Muñón Chimalpahin Cuauhtlehuanitzin, Cristóbal del Castillo, Fernando Alva Ixtlilxochitl e Diego Muñoz Camargo, alguns dos quais filhos de castelhanos e indígenas. ${ }^{54}$

Vale lembrar também que os castelhanos, desde as alianças pré-conquista de Tenochtitlan, necessitavam dessas elites para atender as demandas de seus domínios e, futuramente, de seu império. Era preciso lidar com as unidades políticas mesoamericanas, suas afinidades e tendências à fragmentação e à autonomia, impulsionadas pelas centenas de micro-etnicidades e por um modelo geral de organização celular no qual cada parte da rede de alianças políticas era relativamente completa e, portanto, potencialmente independente. Esse modelo político havia vigorado por milhares de anos e continuava existindo apesar da conquista. Uma demonstração da sua grande força foi o fato

194 de que quase que a totalidade dos altepeme se tornaram municípios na década de 1530, garantindo assim sua sobrevivência como entidade-base da nova organização colonial. Isso garantiu a continuidade da existência de parte da elite nahua que, em troca de privilégios e poderes subordinados, ocupou o governo dessas unidades até o fim do Período Colonial (Lockhart 1992). É claro que isso contribuiu para a continuidade transformada das tradições históricas nahuas que, como vimos, tinham no altepetl seu centro temático.

A rápida expansão do cristianismo pela Mesoamérica durante o século XVI contou também com a realização de uma série de trabalhos missionários de pesquisa, os quais pretendiam aprender as línguas e conhecer os hábitos, a religiosidade e o pensamento nativos. Com esses saberes, os evangelizadores estariam dotados de instrumentos de pregação e preparados para combater as indesejáveis misturas entre as antigas idolatrias e a nova religião e, assim, conseguir uma conversão mais eficiente e inspirada nos ideais do cristianismo primitivo e do milenarismo de Joaquín de Fiore. Os trabalhos realizados ainda no século XVI pelo franciscano Bernardino

\footnotetext{
${ }^{54}$ Suas obras estão referenciadas, respectivamente, como: Alvarado Tezozomoc 1998, Chimalpahin Cuauhtlehuanitzin 1965 e 2001, Castillo 2001, Alva Ixtlilxochitl 1985 e Muñoz Camargo 1998.
} 
de Sahagún (Sahagún 2002) e pelo dominicano Diego Durán (Durán 1984) são os exemplos mais acabados e sofisticados dessas pretensões missionárias de estabelecimento de um cristianismo livre das antigas idolatrias.

Mas esses trabalhos missionários de pesquisa foram realizados em conjunto por freis, por alunos indígenas dos colégios missionários, descendentes das elites locais, e por antigos sábios indígenas. E, desse modo, deram a oportunidade para que uma série de relatos orais, como os huehuetlahtolli, ou antiga palavra, fossem transcritos em nahuatl e depois traduzidos. ${ }^{55}$ Além disso, inúmeros códices pictoglíficos também foram produzidos, glosados ou parcialmente explicados nesses trabalhos conjuntos, dando origem a uma série de textos alfabéticos que "traduziam" os conteúdos tradicionalmente veiculados por meio do sistema pictoglífico. ${ }^{56}$ Esse fato possibilitou o estudo e o entendimento de parte dos códices exclusivamente pictoglíficos.

Em todos esses códices e textos alfabéticos podemos perceber a forte continuidade de elementos utilizados anteriormente pelas tradições históricas nahuas, como por exemplo os relatos cosmogônicos que tratam das eras ou idades anteriores, a utilização da conta dos anos sazonais (xiuhmolpilli) para mensurar as distâncias temporais e estruturar as narrativas e a centralidade dos altepeme nas narrativas que tratavam do passado mais recente. Além disso, podemos perceber também o esforço de adequar os conteúdos dos relatos tradicionais aos novos preceitos cristãos e à cosmogonia do Velho Mundo. Isso se dava, por exemplo, omitindo e minorando nos relatos os episódios de sacrifícios humanos e de antropofagia ou ainda atribuindo-os aos povos inimigos. ${ }^{57}$

\footnotetext{
${ }^{55}$ Os dois principais conjuntos dessas transcrições são os Romances de los señores de la Nueva España e os Cantares mexicanos, ambos publicados sob o título de Poesía náhuatl (2000). Há também uma seção do Códice Florentino, de autoria de Bernardino de Sahagún (Sahagún 2002) e de sua equipe de informantes e alunos indígenas, dedicada aos poemas e cantos tradicionais nahuas.

${ }^{56}$ Entre os textos alfabéticos nahuas que apresentam indícios internos de terem sido produzidos a partir de leituras de códices pictoglíficos, podemos destacar os Anales de Cuauhtitlan (1945), a Historia de los mexicanos por sus pinturas (1996) e a Leyenda de los soles (1945). ${ }^{57}$ Nos Anales de Cuauhtitlan, por exemplo, os mexicas são acusados de sacrificar dezenas de milhares de cativos na inauguração do Templo Maior (Anales de Cuauhtitlan 1945: 57-58). No entanto, alguns cronistas mexicas, como Alvarado Tezozomoc, não omitem os sacrifícios nem os atribuem a outros povos, mas os reivindicam por sua conotação de valentia guerreira e de devoção religiosa - valores locais que seriam compartilhados com os espanhóis, ainda que mal encaminhados pois o demônio teria agido livremente nas terras distantes do Evangelho (Navarrete Linares 2000).
} 
Uma outra forma de adequar os antigos relatos sobre as idades do mundo e a história tolteca às novas demandas era narrá-los novamente à luz dos textos bíblicos. Desse modo, encontramos casos em que Huemac, soberano de Tula e sucessor ou contemporâneo de Quetzalcoatl, foi identificado com o apóstolo São Tomás, numa clara tentativa de vincular os relatos das duas tradições históricas, o que era importante para ambas. Por um lado, as elites indígenas aliadas pretendiam provar que seu mundo e sua história também eram parte da grande história universal cristã, adotada tacitamente no momento de sua conversão. Por outro, o problema da origem do homem americano e de seu esquecimento pelo deus cristão era algo que incomodava aos pensadores cristãos, que também buscavam vincular a América, e o que imaginavam ser sua história, aos relatos bíblicos. ${ }^{58}$

Dentro desse lento e contínuo processo de colonização, o uso da pictografia, um dos principais meios de expressão da tradição histórica nahua, perdurou até fins do século XVII e passou por dois momentos bem distintos (Lockhart 1992). O primeiro, que durou até meados do século XVI, marcouse por uma continuidade geral dos princípios que regiam o sistema, que foi usado inclusive para expressar as novas realidades trazidas pelos castelhanos, como os cavalos e os nomes próprios. Até esse momento, poucos centros haviam iniciado os trabalhos de ensino religioso a jovens ajudantes nahuas - basicamente no México e em Tlaxcala -, que aprenderiam a manejar o alfabeto latino para transcrever seu idioma. O segundo momento, que durou de meados do século XVI até o desaparecimento do sistema, no final do século XVII, marcou-se por um decréscimo constante e progressivo no uso da pictografia como veículo primário, pela proliferação das instalações religiosas e burocráticas castelhanas, pelo conseqüente crescimento da produção de textos alfabéticos de diversos tipos e, por fim, pela adoção de padrões pictóricos europeus.

Além dessas formas de ajuste das explicações tradicionais ao pensamento cristão e apesar da progressiva adoção do sistema alfabético, houve uma grande

\footnotetext{
${ }^{58}$ Essa identificação entre São Tomás e Huemac encontra-se em duas importantes crônicas coloniais: na obra do dominicano Diego Durán (Durán 1984) e no texto do Códice Ramírez (1987), ou Relación del origen de los indios que habitan esta Nueva España, provavelmente um resumo da obra de Durán feito por Juan de Tovar, que fora encarregado pelo vice-rei Martín Enriquez de Almanza para escrever uma história do México pré-hispânico (Camelo \& Rubén Romero 1995). Ou talvez ambos tenham baseado-se em uma obra anterior, perdida e de autoria desconhecida, chamada pelos estudiosos de Crónica $X$.
} 
continuidade, estrutural e temática, da produção local de histórias e cosmogonias até o fim do Período Colonial, sobretudo nas regiões mesoamericanas mais distantes dos centros de poder castelhano. Por vezes, tais continuidades adentraram os séculos XIX e XX e, em última instância, chegaram até os dias atuais. Talvez, de modo geral, possamos dizer que o grau de presença do pensamento cristão nessas histórias e cosmogonias reelaboradas é diretamente proporcional a dois fatores: ao grau de contato, convivência e penetração das instituições de origem ibérica nessas comunidades e também à qualidade dos contatos, isto é, se de maior receptibilidade ou maior rechaço aos elementos de origem estrangeira por parte das comunidades nativas.

Citamos no item anterior que a longa conquista dos incas pelos castelhanos gerou, pelo menos, dois tipos distintos de explicações históricas nativas. Por um lado estavam aquelas que ainda acreditavam na possibilidade de se livrar totalmente da presença castelhana e, por outro, aquelas que já tratavam o fenômeno da invasão como algo irreversível e que procuravam re-localizar, da melhor forma possível, o mundo e a história andina diante da nova situação. Ambas utilizaram-se de conceitos tradicionalmente utilizados pelas explicações históricas incas e que faziam parte da visão de mundo andina em geral, como por exemplo o conceito de pachacuti. Vejamos em detalhe esses dois tipos de explicação histórica colonial, utilizadas pelos incas e povos andinos.

Ainda durante a fase final da conquista militar, em 1564, houve um grande movimento pan-andino, na região de Huamanga, de rechaço ao mundo castelhano chamado de Taki Onqoy ou enfermidade da dança. Segundo os depoimentos de seus participantes - registrados pelo frei Cristóbal de Albornoz e por seu tradutor, Guamán Poma de Ayala -, as guacas estavam zangadas pelo colaboracionismo indígena e pela suspensão dos sacrifícios. Por isso passaram a possuir os indígenas, fazendo-os cair ou dançar ininterruptamente, purificando-os por meio da renúncia ao cristianismo e a tudo o que viesse dos castelhanos. Desse modo, os indígenas acreditavam estar prontos para o próximo pachacuti, quando então as guacas, encabeçadas por Titicaca e Pachacamac, matariam a todos os castelhanos e curacas aliados e assim devolveriam as coisas aos seus devidos lugares (Navarrete Linares 2002).

Podemos perceber nesses depoimentos, de forma muito clara, a presença de pelo menos duas idéias típicas das explicações históricas e da visão de mundo andinas: o mundo divide-se entre hanan e hurin e um pachacuti inverte a posição ocupada por cada uma das partes, como aconteceu durante a conquista castelhana. Além disso, de acordo com a avaliação feita pelos participantes do 
movimento, ainda seria possível expulsar totalmente os estrangeiros e restaurar a antiga ordem das coisas. Inclusive, a ordem restaurada poderia ser uma ordem melhorada, já que o recente domínio inca da região havia sido rompido pelos castelhanos que, por sua vez, seriam expulsos.

A crônica de Titu Cusi Yupanqui (1985) também foi escrita durante essa fase final da conquista, nos anos 1560, e, de um ponto de vista inca, compartilha muitas explicações históricas diante do fenômeno da conquista com o movimento Taki Onqoy. Titu Cusi - irmão de Tupac Amaru, filho de Manco Capac e neto de Huayna Capac - relata centralmente a grande rebelião de Manco Capac, em 1536, e também apresenta um alto grau de rechaço aos castelhanos, classificando-os como seres que não pertenciam a hanan, mas sim a hurin, pois seriam filhos de Supay, o Senhor do Mundo de Abaixo. Nessa classificação podemos perceber outras duas idéias comuns às do Taki Onqoy: a divisão do mundo entre hanan e hurin e a conquista castelhana como um pachacuti que inverteu o mundo antes dominado pelos incas, seres procedentes do mudo superior e do Sol.

A percepção da população nativa, em constante decréscimo numérico, sobre a dimensão do fenômeno colonizador alterou-se com o crescimento da presença castelhana no último terço do século XVI. Essa alteração, conseqüentemente, acarretou a construção de explicações históricas distintas, as quais já não falavam mais em se livrar totalmente dos novos senhores e estrangeiros, mas sim, como citamos anteriormente, em restabelecer as relações de poder e de subordinação de acordo com princípios políticos tradicionais. ${ }^{59}$

No entanto, por outro lado, essa elite era formada por pessoas que haviam crescido e ainda viviam imersos em um universo cultural não muito diferente daquele que existia em tempos incas. Desse modo, suas explicações históricas e cosmogônicas eram, em realidade, construídas com conceitos tradicionais, utilizados cotidianamente para dar conta da realidade natural e social e que faziam parte da própria constituição de seus pensamentos. Reformular as explicações tradicionais da antiga visão de mundo para dar conta da nova realidade e incorporar as idéias cristãs era, muito mais do que um ato deliberada e conscientemente interesseiro, a única forma de obter um certo reconhecimento por

\footnotetext{
${ }^{59}$ É claro que isso as obrigava a uma atitude de abertura e receptividade ainda maior para a instalação das instituições políticas, econômicas e religiosas européias, pois a aliança com os vitoriosos implicava em uma aliança com seus deuses, prática que já possuía precedentes na antiga pauta da política andina (Stern 1986).
} 
parte dos novos senhores, de seus pares e da população indígena em geral, a quem pretendiam representar e comandar desempenhando o papel de intermediários.

Alguns relatos com essas características foram produzidos por membros das elites incas entre o final do século XVI e o início do século XVII e, certamente, podem ser considerados como re-formulações de explicações tradicionais incas que atendiam às novas demandas dos tempos coloniais.

Os escritos mais conhecidos e que se encaixam nesse grupo são os de Felipe Guamán Poma de Ayala, de 1615, os de Juan Santa Cruz Pachacuti Yanqui Salcamayqua, de 1613, e os de Garcilaso de la Vega, de $1609 .{ }^{60}$ Há ainda um texto em quíchua do século XVI, intitulado Manuscrito de Huarochirí ou Runa yndio niscap Machoncuna, que também se encaixaria nesse grupo. ${ }^{61}$ Todos esses escritores incas coloniais e suas tentativas de reelaboração das narrativas históricas e cosmogônicas refletem as demandas de uma época em que já não podiam mais resistir militarmente e buscavam outros meios de oposição e adaptação, como a escrita e os meios legais (Zapata 1989). Entre todos esses escritos, seguramente os que trazem uma maior quantidade de informações específicas do mundo andino são os de Guamán Poma de Ayala e o manuscrito Runa yndio de Huarochirí.

O relato de Guamán Poma pode ser considerado como uma transcrição parcial da tradição histórica inca - única a ser registrada em tempos coloniais ${ }^{62}$ - a partir de narrativas orais, de informações dos quipus e do depoimento de anciãos. Sua obra procurava estabelecer um projeto alternativo à colonização que efetivamente

\footnotetext{
${ }^{60}$ Referenciados, respectivamente, como Guamán Poma de Ayala 1980, Santa Cruz Pachacuti 1968 e Garcilaso de la Vega 1968. No caso da obra de Guamán Poma, além dessa edição em livro, há uma edição fac-similar e eletrônica na Internet (http://www.kb.dk/ elib/mss/poma/) e que conta com comentários de Rolena Adorno e de John Charles.

${ }^{61}$ Esse manuscrito descreve a geografia do Tahuantinsuyu, enfocando principalmente suas guacas e elementos da paisagem tidos como santuários. Suas principais edições são: ARGUEDAS, José María (comp.). Dioses y hombres de Huarochirí: narración quechua. Lima, Museo Nacional de Historia e Instituto de Estudios Peruanos, 1966. / TAYLOR, Gerard. Ritos y tradiciones de Huarochirí: manuscrito quechua, versión paleográfica. Lima, Instituto de Estudios Peruanos e Instituto Francés de Estudios Andinos, 1987. I SALOMON, Frank \& URIOSTE, George. The Huarochiri manuscript: a testament of ancient and colonial Andean religion. Austin, University of Texas Press, 1991.

${ }^{62}$ Parece que o manuscrito Runa yndio de Huarochirí oferece apenas insinuações acerca da existência de outras tradições históricas nos Andes em tempos incaicos (Brotherston 1997: 250).
} 
vinha sendo implantada. Seu principal argumento nesse sentido é que a colonização, do modo como funcionava até então, não beneficiava nem ao rei castelhano nem aos andinos, mas apenas a uns poucos e desonestos conquistadores e burocratas castelhanos e, por isso, deveria ser radicalmente modificada.

Guamán Poma, como sincero membro da igreja católica e testemunho ocular da forte e crescente presença das instituições castelhanas, já não questionava o domínio e a presença cristã nos Andes. Mas, por outro lado, como descendente direto das elites incas, não deixava de acreditar que a conquista havia sido um pachacuti, pois os castelhanos, que deveriam mandar apenas em Castela, mandavam agora também nos Andes. A solução proposta em seus textos para a correção dessa injustiça era a supressão do grupo dos conquistadores e a aliança direta entre os incas, a coroa de Castela e o Papa. ${ }^{63}$

Essa proposta reflete, por um lado, a preocupação da classe dominante indígena em recuperar seus privilégios - cada vez menores diante do crescimento das instituições e do número de burocratas castelhanos - e marca uma reação às sobre-explorações que passaram a caracterizar as relações econômicas e tributárias após 1580. Além disso, as epidemias matavam centenas de

200 milhares e geravam, em muitas partes, um verdadeiro caos social e econômico, explicado pela visão de mundo andina como resultado das relações sociais desequilibradas e que haviam sido implantadas pelos estrangeiros. E, por outro lado, a utilização de conceitos tradicionais - como pachacuti, hanan, hurin e manay - para explicar a conquista e a colonização e construir uma proposta de futuro procurava validá-los mostrando sua eficácia em continuar dando conta das transformações e continuidades da história.

\section{Palavras finais}

Enunciamos de início que a elaboração, a manutenção e a transmissão sistemáticas de explicações acerca do passado não eram, nem o são atualmente, uma exclusividade do mundo ocidental. Afirmamos também que nas chamadas sociedades complexas esses processos tendiam a estar sob o controle de orga-

\footnotetext{
${ }^{63}$ Em seu famoso mapa-múndi, Guamán Poma projeta a divisão quadripartida do Tahuantinsuyu e apresenta os Andes acima de Castela. A maioria de seus desenhos traz contrastes e orientações espaciais que são prioritariamente significativos: são como um arranjo sintático de elementos em uma sentença gramatical (Adorno 1991).
} 
nizações ou grupos específicos que poderiam, inclusive, contar com indivíduos ou instituições especializadas, aos quais denominamos de tradições históricas.

Creio que ao tratarmos, na primeira parte, de algumas características das explicações históricas inca e nahua, pudemos, por um lado, comprovar a existência de tais tradições em tempos pré-hispânicos e, por outro, vislumbrar algumas características de seu funcionamento, principalmente no que diz respeito às preocupações temáticas, à organização estrutural das narrativas, aos mecanismos de registro e transmissão e às concepções de tempo e espaço.

Na segunda parte, ao analisarmos comparativamente as transformações e as continuidades das duas tradições históricas diante das conquistas e colonizações castelhanas, creio que pudemos entender os modos específicos com os quais cada uma reagiu, transformou-se e adaptou-se às novas demandas do mundo colonial. Os resultados dessas transformações e adaptações materializaram-se, muitas vezes, em códices e textos alfabéticos, chamados aqui de escritos históricos, e que devem, portanto, ser situados e analisados dentro dos distintos, complexos e específicos contextos coloniais em que foram produzidos.

A existência dessa grande produção de escritos históricos coloniais nativos apontou para a continuidade transformada de instituições e de saberes de origem indígena, principalmente no primeiro século pós-contato. Isso se comprovou pela utilização de estruturas narrativas - como o calendário no caso nahua - e de conceitos explicativos tradicionais - como o pachacuti no caso inca-nas obras de tempos coloniais. Além disso, houve também uma continuidade da função ideológico-legitimadora que as explicações acerca do passado desempenhavam para as elites indígenas em tempos pré-hispânicos, pois muitos desses escritos coloniais tinham como principal preocupação a adequação das antigas explicações históricas e cosmogônicas ao pensamento histórico-religioso dos novos senhores, redefinindo e garantindo assim uma nova identidade e uma nova posição política para as tais elites na nova ordem colonial.

Vimos também, que o modo pelo qual se logrou a conquista dos incas e dos nahuas pelos castelhanos foi um fator determinante na constituição das redes de alianças que imperaram no mundo andino e mesoamericano colonial, e que isso influenciou diretamente o posicionamento de maior adesão ou rechaço aos novos senhores, o que, por sua vez, teve implicações diretas nas formas de reelaboração histórica levadas a cabo pelas tradições históricas locais.

Podemos dizer que a rápida conquista dos mexicas pelos castelhanos e indígenas aliados contribuiu para uma maior legitimidade relativa e para a aceitação da nova ordem pelos grupos locais. Isso, por sua vez, contribuiu para uma 
maior rapidez e facilidade de traslado de instituições castelhanas, sobretudo de instituições religiosas, o que resultou em um grau muito maior de influência e de presença cristãs nas novas explicações históricas nativas. Tais produções, em geral, destinavam-se a leitores dos dois universos culturais, pois necessitavam, simultaneamente, do reconhecimento local e da aprovação dos novos e estrangeiros senhores para lograr uma re-localização do passado e do presente indígena a partir das novidades adotadas ou impostas pela tradição de pensamento cristã.

Já a dificultosa e prolongada conquista dos incas pelos castelhanos e seus poucos aliados teve como resultado uma menor legitimidade relativa do poder dos novos senhores aos olhos dos princípios políticos locais, o que ocasionou uma maior dificuldade no traslado e na implantação das instituições castelhanas, tornando-as mais tardias e menos difundidas geograficamente em relação à região central do México.

Entre uma série de outros fatores, essas diferenças no processo de conquista e colonização dos Andes contribuíram para importantes particularidades na produção das explicações históricas locais em relação às produções do Altiplano Central. Tratamos mais detalhadamente de duas dessas particularidades: 1 - a presença central e difundida da concepção de que a conquista castelhana havia 202 sido um pachacuti, uma inversão total da antiga ordem de coisas, e que seria possível, em um futuro breve, revertê-la totalmente; 2 - a não-aceitação do poder político e econômico dos conquistadores e burocratas como algo legítimo, fato que levou um dos mais importantes cronistas coloniais incas a elaborar um projeto de vinculação direta das elites locais ao rei de Castela e ao Papa. ${ }^{64}$

Creio que todas essas reflexões nos apontam para a importância de analisarmos a problemática da qualidade dos contatos entre indígenas e europeus e da postura adotada por cada grupo nos processos de conquista e de coloni-

\footnotetext{
${ }^{64}$ É claro que isso também levou a um número muito maior de rebeliões e revoltas nos Andes do que no México Central, onde elas praticamente não ocorreram durante todo o Período Colonial. Situação distinta viveu a região maia, na qual, assim como nos Andes, houve um longo e dificultoso processo de conquista e colonização, que resultou em uma sociedade colonial extremamente cindida e na qual os castelhanos careciam de legitimidade aos olhos da política indígena. No caso dos maias, também houve inúmeras rebeliões durante todo o Período Colonial.

${ }^{65}$ Isso não significa que o grau de contato seja uma variável menos importante. Vale lembrar que as regiões mais distantes dos centros de poder castelhano apresentaram uma continuidade de funcionamento das tradições históricas nativas muito maior, chegando, em alguns casos, até o século XX; enquanto que nos centros de poder castelhano, a maioria das tradições locais desapareceu antes do fim do Período Colonial.
} 
zação castelhana - e não apenas o grau de contato, mensurado em distância, tempo e presença de instituições castelhanas. ${ }^{65}$ Talvez, o enorme e multicolorido leque de casos que essas análises irão nos revelar tornará necessária a reavaliação da validade e do alcance explicativo de conceitos que, durante décadas, foram aplicados para dar conta de todos os contatos entre europeus e indígenas, como por exemplo os conceitos de mestiçagem e de aculturação.

\section{Bibliografia}

\section{Fontes}

ACOSTA, José de. Historia natural y moral de las Indias. 2a . edição. México, Fondo de Cultura Económica, 1985.

ALVA IXTLILXOCHITL, Fernando de. Obras históricas. México, Universidad Nacional Autónoma de México, 1985.

ALVARADO TEZOZOMOC Fernando. Crónica Mexicayotl. $3^{\text {a }}$. edição. México, Universidad Nacional Autónoma de México, 1998.

"Anales de Cuauhtitlan". in Códice Chimalpopoca: Anales de Cuauhtitlan y Leyenda de los soles. México, Universidad Nacional y Autónoma de México, 1945, pp. 03-118.

CASTILLO, Cristóbal. Historia de la venida de los mexicanos y de otros pueblos / Historia de la conquista. México, Conaculta, 2001.

CHIMALPAHIN CUAUHTLEHUANITZIN, Domingo Francisco de San Antón Muñón. Diario. México, Conaculta, 2001.

CHIMALPAHIN CUAUHTLEHUANITZIN, Domingo Francisco de San Antón Muñón. Relaciones originales de Chalco Amaquemecan. México, Fondo de Cultura Económica, 1965.

Códice Boturini o Tira de la peregrinación. México, Secretaría de Educación Pública, 1975.

"Códice Ramirez - manuscrito del siglo XVI intitulado Relación del origen de los indios que habitan esta Nueva España según sus historias". in Crónica Mexicana y Códice Ramirez. $4^{a}$ edição. México, Editorial Porrúa, 1987, pp. 17-149.

Códice Vaticano A - Religión, costumbres e historia de los antiguos mexicanos. Áustria, Akademische Druck-und Verlagsanstalt \& México, Fondo de Cultura Económica, 1996. 
DURÁN, Diego. Historia de las indias de Nueva España e islas de la tierra firme. 2a. edição. México, Editorial Porrúa, 1984.

GARCILASO DE LA VEGA, Inca. Comentarios reales: el origen de los incas. Barcelona, Editorial Bruguera, 1968.

GUAMÁN POMA DE AYALA, Felipe. El primer nueva corónica y buen gobierno. México, Siglo XXI, 1980.

"Historia de los mexicanos por sus pinturas". in Teogonía e historia de los mexicanos: tres opúsculos del siglo XVI. $5^{\text {a }}$. edição. México, Editorial Porrúa, 1996, pp. 23-90.

"Leyenda de los soles". in Códice Chimalpopoca: Anales de Cuauhtitlan y Leyenda de los soles. México, Universidad Nacional Autónoma, 1945, pp. 119-142.

Libro de Chilam Balam de Chumayel. 2a . edição. México, Conaculta, 2001.

MUÑOZ CAMARGO, Diego. Historia de Tlaxcala. México, Gobierno del Estado de Tlaxcala \& Ciesas \& Universidad de Tlaxcala, 1998.

Poesía náhuatl. Romances de los señores de la Nueva España e Cantares Mexicanos. 2a. edição. México, Universidad Nacional Autónoma de México, 2000.

Popol Vuh - Las antiguas historias del Quiché. 26a. edição. México, Fondo de Cultura Económica, 1996.

SAHAGÚN, Bernardino de. Historia general de las cosas de Nueva España. Versión íntegra del manuscrito castellano conocido como Códice Florentino. $3^{a}$. edição. México, Conaculta, 2002.

SANTA CRUZ PACHACUTI, Juan. Relación de antiguedades deste reyno del Perú... Madrid, Ediciones Atlas, 1968.

TITU CUSSI YUPANGUI. Ynstrución del Ynga don Diego de Castro Titu Cusi Yupangui para el muy ilustre señor... Lima, Ediciones El Virrey, 1985.

\section{Obras historiográficas}

ADORNO, Rolena. Guaman Poma - writing and resistance in Colonial Peru. $2^{\mathrm{a}}$. edição. Austin, University of Texas Press, 1991.

ASCHER, Marcia \& ASCHER, Robert. "El quipu como lenguage visible". in LECHTMAN, Heather \& SOLDI, Ana María (org). La tecnología en el mundo andino. Tomo I: subsistencia y mensuración. $2^{\mathrm{a}}$. edição. México, Universidad Nacional Autónoma de México, 1985, pp. 407-432. 
ASCHER, Marcia \& ASCHER, Robert. Mathematics of the Incas. Code of the Quipu. Meneloa. New York, Dover Publications, 1997.

BORGES, Pedro. "La emigración de eclesiásticos a América en el siglo XVI. Criterio para su estudio" in SOLANO, Francisco \& PINO, Fermín del (org) América y la España del siglo XVI. Vol. II. Madrid, Instituto Gonzalo Fernandez de Oviedo, 1983, pp. 47-62.

BROTHERSTON, Gordon. La América indígena en su literatura: los libros del cuarto mundo. México, Fondo de Cultura Económica, 1997.

CAMELO, Rosa \& ROMERO, José Rubén. "Estudio preliminar”. In DURÁN, Fray Diego. Historia de las Indias de Nueva España e islas de tierra firme. México, Conaculta, 1995.

CASTILLO FARRERAS, Víctor. "El bisiesto náhuatl”. in LÓPEZ AUSTIN, Alfredo \& LEÓN PORTILLA, Miguel (editores). Estudios de cultura náhuatl. Vol. 9. México, Universidad Nacional Autónoma de México, 1971, pp. 75-104.

DÍEZ CANSECO, María Rostworowski. "Mediciones y cómputos en el antiguo Perú". in LECHTMAN, Heather \& SOLDI, Ana María (org). La tecnología en el mundo andino. Tomo I: subsistencia y mensuración. $2^{\mathrm{a}}$. edição. México, Universidad Nacional Autónoma de México, 1985, pp. 379-405.

FRASER, Valerie. Texto e significado na América nativa. Material de curso ministrado no MAE-FFLCH/USP durante o primeiro semestre de 2003.

GLASS, John B. \& ROBERTSON, Donald. "A census of native Middle American pictorial manuscripts". in WAUCHOPE, Robert (editor geral) \& CLINE, Howard F. (editor dos volumes). Handbook of Middle American Indians. vol. 14. Austin e Londres, University of Texas Press, 1975, pp. 81-251.

GRAULICH, Michel. Mitos y rituales del México antiguo. Madrid, Colegio Universitario \& Ediciones Istmo, 1990.

LOCKHART, James. The nahuas after the conquest. A social and cultural history of the indias of Central Mexico, sixteenth through eighteenth centuries. Stanford, Stanford University Press, 1992.

LÓPEZ AUSTIN, Alfredo. La construcción de una visión de mundo. Material de curso ministrado no Instituto de Investigaciones Antropológicas da UNAM, México, no primeiro semestre do ano letivo 2002-2003.

MANRIQUE CASTAÑEDA, Leonardo. "Ubicación de los documentos pictográficos de tradición náhuatl en una tipología de sistemas de registro y de escritura”. in MARTÍNEZ MARÍN, Carlos. Primer coloquio de 
documentos pictográficos de tradición náhuatl. México, Universidad Nacional Autónoma de México, 1989, pp. 159-170.

MILLONES, Luis. Historia y poder en los Andes Centrales: desde los orígenes al siglo XVII. Madrid, Alianza Editorial, 1987.

MOLINA, Alonso de. Vocabulario en lengua castellana y mexicana y mexicana y castellana. 4a . edição. México, Editorial Porrúa, 2001.

MONTOYA ROJAS, Rodrigo. "Historia, memoria y olvido en los Andes quechuas" in PORTELLA, Eduardo (diretor). Revista Tempo Brasileiro História: Memória e Esquecimento. Rio de Janeiro, Edições Tempo Brasileiro, no. 135, pp. 157-180, outubro/dezembro de 1998a.

MONTOYA ROJAS, Rodrigo. Cultura e violência no Peru: como se transforma a cultura? Material de curso ministrado no Depto. de História da FFLCH/ USP durante o segundo semestre de 1998.

MURRA, John V. "Las etnocategorías de un khipu estatal". in LECHTMAN, Heather \& SOLDI, Ana María (org). La tecnología en el mundo andino. Tomo I: subsistencia y mensuración. $2^{\mathrm{a}}$. edição. México, Universidad Nacional 206 Autónoma de México, 1985, pp.434-442.

NAVARRETE LINARES, Federico. Mito, historia y legitimidad política: las migraciones de los pueblos del Valle de México. tese de doutoramento, México, Universidad Nacional Autónoma de México, 2000.

NAVARRETE LINARES, Federico. Visão comparativa da conquista e colonização das sociedades indígenas estatais: nahuas, maias e incas. Material de curso ministrado no Depto de História da FFLCH/USP durante o primeiro semestre de 2002.

PEASE G. Y., Franklin. Las crónicas y los Andes. Lima, Pontificia Universidad Católica del Perú \& México, Fondo de Cultura Económica, 1995.

RÉMI SIMÉON. Diccionario de la lengua náhuatl o mexicana - redactado según los documentos impresos y manuscritos más auténticos y precedido de una introducción. 14a . edição. México \& Madrid, Siglo Veintiuno Editores, 1997.

SALOMON, Frank "Chronicles of the Impossible. Notes on three Peruvian Indigenous Historians" in ADORNO, Rolena (org). From Oral to Written Expression. Native Andean Chronicles of the Early Colonial Period. Syracuse, Syracuse University, 1982, pp. 9-39. 
SANTOS, Eduardo Natalino dos. "A construção de uma nova memória mesoamericana: reflexões sobre a produção histórico-literária de religiosos espanhóis na região do Vale do México no século XVI”. in PORTELLA, Eduardo (diretor) Revista Tempo Brasileiro - História: Memória e Esquecimento. Rio de Janeiro: Edições Tempo Brasileiro, nº. 135, pp. 181196, outubro/dezembro de 1998.

SANTOS, Eduardo Natalino dos. "Códices mexicas: soluções figurativas a serviço da escrita pictoglífica". in ARARA - Art and Architecture of the Americas. Essex, Department of Art and Theory - University of Essex, nº 5, http:// www2.essex.ac.uk/arthistory/arara/issue five/paper3.html desde 24 de junho de 2003.

SANTOS, Eduardo Natalino dos. Deuses do México indígena. Estudo comparativo entre narrativas espanholas e nativas. São Paulo, Editora Palas Athena, 2002.

STERN, Steve J. Los pueblos indígenas del Perú y el desafío de la conquista española, Huamanga hasta 1640. Madrid, Alianza Editorial, 1986.

TENA, Rafael. El calendário mexica y la cronografía. México, Instituto Nacional de Antropología e Historia, 1992.

URTON, Gary. Quipu: contar anudando en el imperio inka. Santiago, Museo Chileno de Arte Precolombino \& Universidad de Harvard, 2003.

Vocabulário ortográfico da língua portuguesa. Academia Brasileira de Letras. $3^{a}$. edição. Rio de Janeiro, A Academia, 1999.

ZAPATA, Roger A. Guamán Poma: indigenismo y estética de la dependencia en la cultura peruana. Minneapolis, Institute for the Study of Ideologies and Literature, 1989. 